\title{
How accurately can soil organic carbon stocks and stock changes be quantified by soil inventories?
}

\author{
M. Schrumpf ${ }^{1}$, E. D. Schulze ${ }^{1}$, K. Kaiser ${ }^{2}$, and J. Schumacher ${ }^{3}$ \\ ${ }^{1}$ Max-Planck-Institute for Biogeochemistry, Jena, Germany \\ ${ }^{2}$ Soil Sciences, Martin Luther University Halle-Wittenberg, Halle, Germany \\ ${ }^{3}$ Institute for Stochastics, Friedrich-Schiller-University Jena, Jena, Germany \\ Received: 10 November 2010 - Published in Biogeosciences Discuss.: 24 January 2011 \\ Revised: 16 April 2011 - Accepted: 3 May 2011 - Published: 18 May 2011
}

\begin{abstract}
Precise determination of changes in organic carbon (OC) stocks is prerequisite to understand the role of soils in the global cycling of carbon and to verify changes in stocks due to management. A large dataset was collected to form base to repeated soil inventories at 12 CarboEurope sites under different climate and land-use, and with different soil types. Concentration of OC, bulk density (BD), and fine earth fraction were determined to $60 \mathrm{~cm}$ depth at 100 sampling points per site. We investigated (1) time needed to detect changes in soil OC, assuming future re-sampling of 100 cores; (2) the contribution of different sources of uncertainties to OC stocks; (3) the effect of OC stock calculation on mass rather than volume base for change detection; and (4) the potential use of pedotransfer functions (PTF) for estimating BD in repeated inventories.

The period of time needed for soil OC stocks to change strongly enough to be detectable depends on the spatial variability of soil properties, the depth increment considered, and the rate of change. Cropland sites, having small spatial variability, had lower minimum detectable differences (MDD) with 100 sampling points $\left(105 \pm 28 \mathrm{gC} \mathrm{m}^{-2}\right.$ for the upper $10 \mathrm{~cm}$ of the soil) than grassland and forest sites $(206 \pm 64$ and $246 \pm 64 \mathrm{gC} \mathrm{m}^{-2}$ for $0-10 \mathrm{~cm}$, respectively). Expected general trends in soil OC indicate that changes could be detectable after $2-15 \mathrm{yr}$ with 100 samples if changes occurred in the upper $10 \mathrm{~cm}$ of stone-poor soils. Error propagation analyses showed that in undisturbed soils with low stone contents, OC concentrations contributed most to OC stock variability while $\mathrm{BD}$ and fine earth fraction were more important in upper soil layers of croplands and in stone rich soils. Though the calculation of OC stocks based on equivalent
\end{abstract}

Correspondence to: $\mathrm{M}$. Schrumpf (mschrumpf@bgc-jena.mpg.de) soil masses slightly decreases the chance to detect changes with time at most sites except for the croplands, it is still recommended to account for changing bulk densities with time. Application of PTF for the estimation of bulk densities caused considerable underestimation of total variances of OC stocks if the error associated with the PTF was not accounted for, which rarely is done in soil inventories. Direct measurement of all relevant parameters approximately every $10 \mathrm{yr}$ is recommended for repeated soil OC inventories.

\section{Introduction}

Soils represent the most important long-term organic carbon (OC) reservoir in terrestrial ecosystems, as they contain more C than plant biomass and the atmosphere (Schimel, 1995; Tarnocai et al., 2009). The large soil reservoir is not permanent but results from a dynamic equilibrium between organic and inorganic material entering and leaving the soil. Therefore, $\mathrm{C}$ stored in soils is affected by changes in vegetation and plant growth, removal of biomass by harvest, and mechanical soil disturbances such as plowing. Soil $\mathrm{C}$ is further sensitive to environmental changes such as global warming or nitrogen deposition (von Lützow and Kögel-Knabner, 2009; Janssens et al., 2010). The European carbon balance indicates that, on average, soils under forests and grasslands are net $\mathrm{C}$ sinks of $20 \pm 12 \mathrm{~g} \mathrm{~m}^{-2} \mathrm{yr}^{-1}$ and $57 \pm 34 \mathrm{~g} \mathrm{~m}^{-2} \mathrm{yr}^{-1}$, respectively, while croplands are minor sources of $10 \pm 9 \mathrm{gC} \mathrm{m}^{-2} \mathrm{yr}^{-1}$ (Schulze et al., 2009). The rates were approximated via modeling and input-output balances with high uncertainties. Consequently, direct measurements by repeated soil inventories are urgently needed to further constrain these estimates (Schulze et al., 2009).

Published by Copernicus Publications on behalf of the European Geosciences Union. 
A number of regional and national soil inventories and monitoring networks are currently established or tested for their suitability to verify soil carbon changes. This would be necessary if soil $\mathrm{C}$ sequestration should be accountable according to the United Nations Framework Convention on Climate Change (Saby et al., 2008b; Rodeghiero et al., 2010b). To date, field-based measurements of soil organic carbon (SOC) changes are scarce and hampered by the inherently high spatial variability of SOC stocks at multiple scales (Palmer et al., 2002; Conant and Paustian, 2002; Conen et al., 2005; Garten and Wullschleger, 1999). It is not possible to detect changes in SOC by repeated inventories unless very high sample numbers are used and the cumulative changes with time are large enough to be detectable. Garten and Wullschleger (1999) estimated that more than 100 samples would be necessary to detect a $2-3 \%$ change in soil OC stocks, and Conen et al. (2005) concluded that with a sample size of 100, soil OC stock changes between 120 and $2480 \mathrm{~g} \mathrm{~m}^{-2}$ can be detected, depending on local site conditions. Smith (2004) estimated that $10-15 \mathrm{yr}$ are needed to detect a change in SOC stocks following a shift in soil C inputs by $15 \%$, assuming a sampling design that allows for detection of a $3 \%$ change relative to background stocks.

Calculation of soil carbon stocks of a site requires determination of soil OC concentrations, bulk densities (BD), stone contents, and soil depth, which all vary in space and have different measurement errors associated. Thus, the question arises, if all these variables contribute similarly to the variability of SOC stocks. Don et al. (2007) observed higher relative variability of SOC concentrations than of bulk densities at two German grassland sites. Similarly, Goidts et al. (2009a) found across different spatial scales that OC concentrations and stone contents were usually more important than BD in Belgian (Wallonian) grassland and cropland sites. They further made the important point that the variables are not independent of each other, and that the covariance between them needs to be considered as well when analyzing variability of SOC stocks. So far, no study included forest sites, and the general applicability of the results and the determining factors are still to be proven.

Long-term soil monitoring at the plot scale without changes in land use or management often showed insignificant changes in SOC or inconsistent temporal and spatial trends (Hopkins et al., 2009; Kiser et al., 2009; Johnson et al., 2007; Fahey et al., 2005). Available regional European assessments show a large range in detected trends and fluxes for different land use types (Table 1). Many more studies focused on agricultural soils than on forests, and most are from one single country, Belgium. Three out of the four studies on forests and five out of nine studies on grasslands indicate SOC gains, and 11 out of 14 studies on croplands indicate SOC losses (Table 1). The losses of SOC observed by Bellamy et al. (2005) across all land use types in the UK cannot be confirmed across Europe. Still, if only changes since 1990 are considered, all studied croplands or grasslands (for grasslands only studies from Belgium are available) lost C. Detected changes ranged between 4 and $12 \%$ of background stocks over $10 \mathrm{yr}$.

Regional assessments of SOC changes usually have to rely on soil surveys not originally designed for assessing SOC stock changes. Often only OC concentrations but not BD or stone contents were directly determined. In such cases, either only changes in OC concentrations are presented or pedotransfer functions (PTF) are used to estimate BD and translate concentration changes into fluxes per area (Table 1). This can have significant effects on the resulting fluxes (Smith et al., 2007; Hopkins et al., 2009). In most studies, BD derived from PTF are simply applied for the determination of SOC stocks without accounting for the error associated with the estimation of $\mathrm{BD}$, though it induces additional uncertainty to calculated SOC stocks.

Another factor frequently overlooked in the repeated soil inventories published to date is that, besides OC concentrations, BD also varies with time. First, it will simply shift because of its general dependence on OC concentrations. Also other factors like swelling and shrinking with changing water contents affect BD. Hopkins et al. (2009) showed that drying to the wilting point reduced the volume of soil samples of clay loam texture by $6-31 \%$. Similarly, changes in land use or tillage regime will influence BD (Ellert and Bettany, 1995; Ellert et al., 2001). To account for this, Ellert and Bettany (1995) suggested the calculation of element stocks based on equivalent soil masses per area instead of soil volumes to a fixed soil depth. As the equivalent soil mass method is also less affected by errors induced by soil compaction during soil sampling, it was recently recommended with some modifications for comparisons of SOC stocks (Ellert et al., 2002; Wuest, 2009; Gifford and Roderick, 2003; Lee et al., 2009). On the other hand, the reduction or enlargement of a sampled soil layer to achieve a predefined soil mass will cause additional errors in calculated SOC stocks (Gifford and Roderick, 2003). It was not tested so far if this recalculation of OC stocks affects their variability and the detection of changes.

The CarboEurope network includes monitoring sites all over Europe, under different land use, and in different climatic regions. At these sites, environmental variables such as air and soil temperature, precipitation, and soil moisture are continuously monitored, and estimates of net ecosystem C fluxes (NEE) are available. We took advantage of this unique opportunity to create a base for repeated stocktaking at 12 sites. First soil samples were taken in the year 2004, at 100 geo-referenced points within the footprint area of each eddy covariance tower down to a soil depth of at least $60 \mathrm{~cm}$ in stone-poor soils. Samples were analyzed for OC concentration, bulk density, and content of stones and roots. The negative relation between BD and OC concentrations was used to derive a pedotransfer function specific for the study sites, with known errors. 
Table 1. Summary of European studies on changes in soil organic carbon by repeated soil inventories at the regional scale.

\begin{tabular}{|c|c|c|c|c|c|c|c|}
\hline $\begin{array}{l}\text { Country } \\
\text { (region) }\end{array}$ & $\begin{array}{l}\text { Soil depth } \\
\text { (cm) }\end{array}$ & $\mathrm{BD}$ & $\begin{array}{l}\triangle \mathrm{SOC} \\
\left(\mathrm{g} \mathrm{kg}^{-1} \mathrm{yr}^{-1}\right)\end{array}$ & $\begin{array}{l}\triangle \mathrm{SOC} \\
\left(\mathrm{g} \mathrm{m}^{-2} \mathrm{yr}^{-1}\right)\end{array}$ & $\begin{array}{l}\text { Relative } \\
\text { change } \\
(\%)\end{array}$ & $\begin{array}{l}\text { Relative } \\
\text { change } \\
\left(\% \mathrm{yr}^{-1}\right)\end{array}$ & $\begin{array}{l}\text { Period } \\
\text { (years) }\end{array}$ \\
\hline \multicolumn{8}{|l|}{ All land uses } \\
\hline $\begin{array}{l}\text { England and } \\
\text { Wales (UK) }{ }^{1}\end{array}$ & $0-15$ & $\mathrm{PTF}$ & -0.64 & -31 & & -0.6 & $\begin{array}{l}1978-2003 \\
(12-25)\end{array}$ \\
\hline \multicolumn{8}{|l|}{ Croplands } \\
\hline Belgium (Flanders) ${ }^{3}$ & $\begin{array}{l}0-24 \text { measured, } \\
\text { estimated for } \\
0-100\end{array}$ & PTF & -0.22 & -90 & -12 & -1.08 & $\begin{array}{l}1989-2000 \\
\text { (11) }\end{array}$ \\
\hline Belgium $^{4}$ & $0-100$ & PTF & & -39 & -4 & -0.44 & $\begin{array}{l}1990-2000 \\
(10)\end{array}$ \\
\hline Belgium $^{5}$ & & & & -3 & & & $\begin{array}{l}1960-2000 \\
(40)\end{array}$ \\
\hline $\begin{array}{l}\text { Belgium } \\
\text { (Wallonia) }\end{array}$ & Plow layer & $\begin{array}{l}\text { 1955: PTF } \\
\text { 2005: measured }\end{array}$ & -0.05 & -11 & -13 & -0.25 & $\begin{array}{l}1955-2005 \\
(50)\end{array}$ \\
\hline $\begin{array}{l}\text { Belgium } \\
\text { (Wallonia) }^{7}\end{array}$ & Plow layer & measured? & & -16 & -16 & -0.32 & $\begin{array}{l}1955-2005 \\
(50)\end{array}$ \\
\hline $\begin{array}{l}\text { Belgium } \\
\text { (West Flanders) }^{8}\end{array}$ & Plow layer & - & +0.05 & +23 & 19 & +0.48 & $\begin{array}{l}1952-1992 \\
(40)\end{array}$ \\
\hline $\begin{array}{l}\text { Belgium } \\
\text { (Flanders) })^{9}\end{array}$ & $\begin{array}{l}0-30 \\
0-100\end{array}$ & PTF & & $\begin{array}{l}-15 \\
-19\end{array}$ & $\begin{array}{l}13 \\
10\end{array}$ & $\begin{array}{l}-0.28 \\
-0.21\end{array}$ & $\begin{array}{l}1960-2006 \\
(46)\end{array}$ \\
\hline Austria $^{10}$ & $0-20$ & - & $\begin{array}{l}-0.46 \\
-0.07\end{array}$ & $\begin{array}{l}-29 \\
-12\end{array}$ & $\begin{array}{l}-16 \\
-6\end{array}$ & $\begin{array}{l}-0.62 \\
-0.23\end{array}$ & $\begin{array}{l}1965-1991 \\
(\sim 26)\end{array}$ \\
\hline Finland $^{15}$ & $0-20$ & - & -0.25 & n.d. & 8 & -0.77 & $\begin{array}{l}1987-1998 \\
(11)\end{array}$ \\
\hline \multicolumn{8}{|l|}{ Grasslands } \\
\hline $\begin{array}{l}\text { Belgium } \\
\text { (Flanders) }^{16}\end{array}$ & $\begin{array}{l}0-100 \\
\text { (modelled from } \\
\text { topsoil) }\end{array}$ & $\begin{array}{l}\text { averaged BDs } \\
\text { used }\end{array}$ & $-0.35^{\mathrm{b}}$ & $\begin{array}{l}-150 \\
-29^{b}\end{array}$ & $\begin{array}{l}10 \\
2\end{array}$ & $\begin{array}{l}-0.95 \\
-0.19^{\mathrm{b}}\end{array}$ & $\begin{array}{l}1990-2000 \\
(10)\end{array}$ \\
\hline Belgium $^{4}$ & $0-100$ & PTF & & -82 & 6 & -0.59 & $\begin{array}{l}\text { 1990-2000 } \\
(10)\end{array}$ \\
\hline \multirow[t]{3}{*}{ Belgium $^{5}$} & $0-30$ & PTF & & +46 & 20 & +0.66 & $\begin{array}{l}1960-1990 \\
(30)\end{array}$ \\
\hline & & & & -50 & 6 & -0.60 & $\begin{array}{l}\text { 1990-2000 } \\
(10)\end{array}$ \\
\hline & & & & +23 & 13 & +0.33 & $\begin{array}{l}1960-2000 \\
(40)\end{array}$ \\
\hline $\begin{array}{l}\text { Belgium } \\
\text { (Wallonia) }\end{array}$ & $0-30$ & $\begin{array}{l}\text { PTF for } 1955 \\
\text { measured } 2005\end{array}$ & +0.12 & +42 & 36 & +0.72 & $\begin{array}{l}1955-2005 \\
(50)\end{array}$ \\
\hline $\begin{array}{l}\text { Belgium } \\
\text { (Wallonia) }^{7}\end{array}$ & Plow layer & measured? & & +15 & 9 & +0.18 & $\begin{array}{l}1955-2005 \\
(50)\end{array}$ \\
\hline Belgium & $0-30$ & PTF & & -0 & 0 & -0.01 & 1960-2006 \\
\hline$(\text { Flanders })^{9}$ & $0-100$ & & & +14 & 6 & +0.14 & $(46)$ \\
\hline
\end{tabular}


Table 1. Continued.

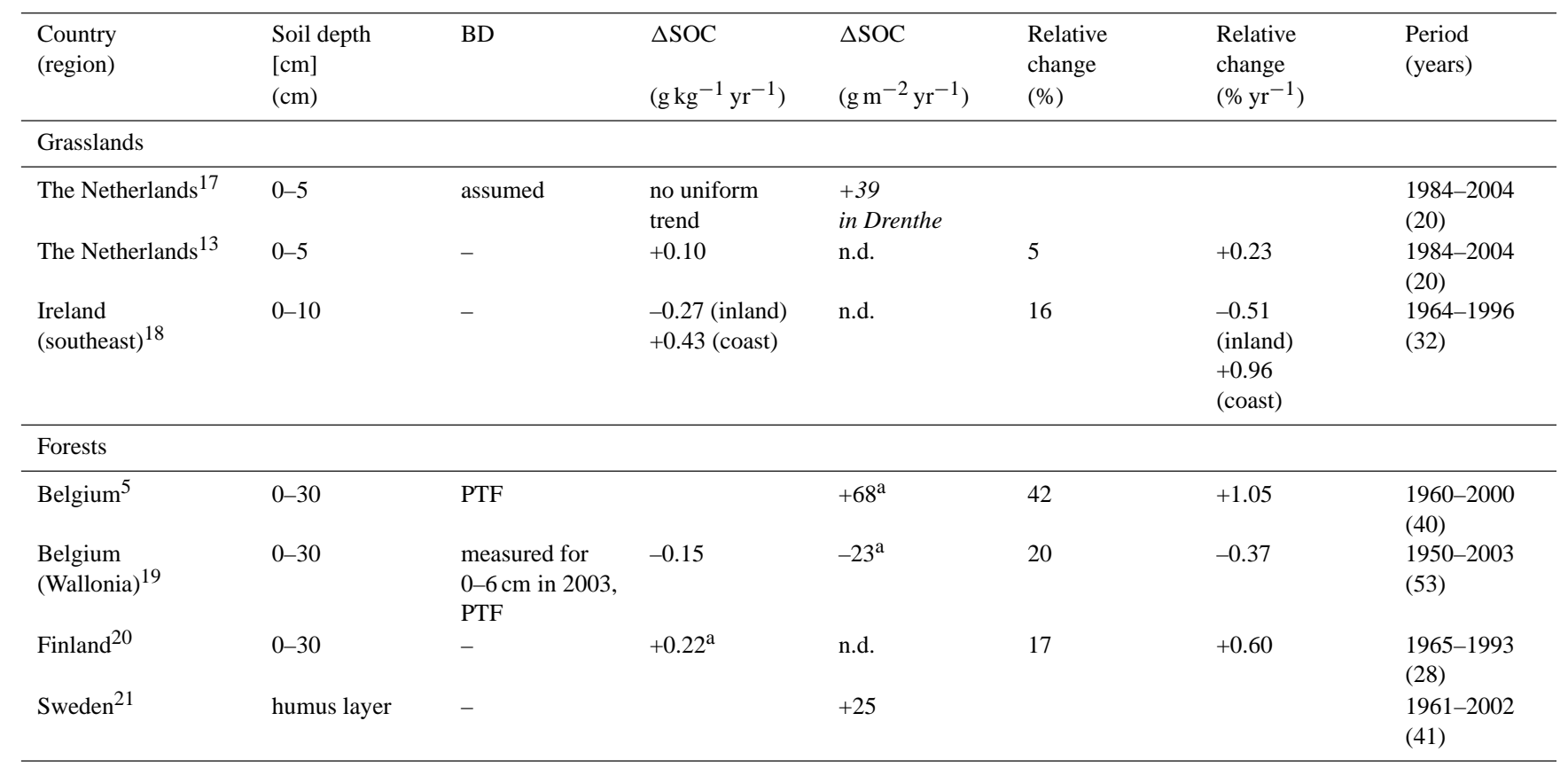

PTF: pedotransfer function; ${ }^{\mathrm{a}}$ only mineral soil; ${ }^{\mathrm{b}}$ derived from linear regression;

${ }^{1}$ Bellamy et al. (2005); ${ }^{2}$ Sleutel et al. (2006); ${ }^{3}$ Sleutel et al. (2003); ${ }^{4}$ Lettens et al. (2005b); ${ }^{5}$ Lettens et al. (2005a); ${ }^{6}$ Goidts and van Wesemael (2007); ${ }^{7}$ Goidts et al. (2009b); 8 van Meirvenne et al. (1996); ${ }^{9}$ Meersmans et al. (2009); ${ }^{10}$ Dersch and Böhm (1997); ${ }^{11}$ Heidmann et al. (2002); ${ }^{12}$ Riley and Bakkegard (2006); ${ }^{13}$ Reijneveld et al. (2009);

${ }^{14}$ Saby et al. (2008a); ${ }^{15}$ Mäkelä-Kurtto and Sippola (2002); ${ }^{16}$ Mestdagh et al. (2009); ${ }^{17}$ Hanegraaf et al. (2009); ${ }^{18}$ Zhang and McGrath (2004); ${ }^{19}$ Stevens and van Wesemael (2008); ${ }^{20}$ Tamminen and Derome (2005); ${ }^{21}$ Berg et al. (2009).

We used this extensive database to test the following hypothesis:

1. Repeated sampling of 100 soil cores is sufficient at the plot/field scale to determine soil OC changes within five to ten years.

2. The relative contribution of $\mathrm{OC}$ concentration, BD and stone content to the variance of SOC stocks is sitedependent and changes with soil depth.

3. The equivalent soil mass method for the calculation of SOC stocks will hamper the detection of changes (increase in MDD) by additional uncertainty induced by the recalculation of stocks.

4. Application of PTF increases the relative contribution of BD to the total variance of SOC stocks, and failure to account for the error associated with the estimation of $\mathrm{BD}$ results in significant underestimation of the MDD.

\section{Methods}

\subsection{Study sites}

Out of a total of 52 main sites of the CarboEurope Integrated Program, 12 were selected to give a geographical spread across Europe, and to cover major land use types (deciduous and coniferous forests, grasslands, and croplands). Continuous recording of flux data for eddy covariance analyses during the period between first sampling and re-sampling had to be assured. The location of the selected sampling sites is illustrated in Fig. 1, coordinates, soil types, and average annual rainfall and temperatures are presented in Table 2.

\subsection{Sampling scheme}

The aim of the project was to compare potential changes in SOC with flux measurements and to test for the influence of differing soil properties on NEE estimates. Therefore, the main fetch of the eddy covariance towers defined the sampling area at each site. The footprint area of eddy covariance towers depends on their height, and wind speed and direction. Consequently, footprint areas vary in size and shape between sites. Preliminary statistical analyses showed that a sample number of 100 would be a good compromise between practicality and having a fair chance to detect changes at the plot scale. The 100 sampling points per site formed a regular grid at distances of 10 to $15 \mathrm{~m}$ at the grassland and cropland sites (with smaller footprints and sampling plots of 1-2 ha), and $30 \mathrm{~m}$ at the forest sites (plot sizes of 7-8 ha, only at the Hainich site, plot size was 24 ha due to an overall larger grid). 


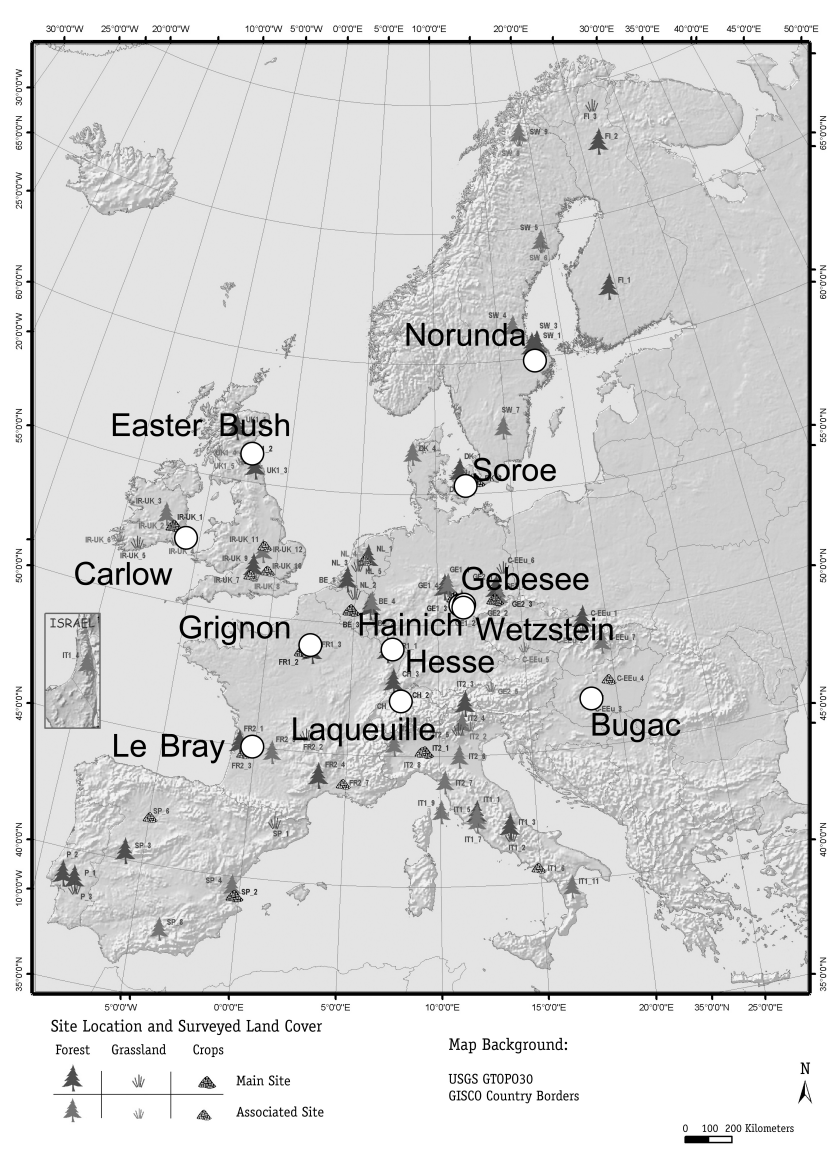

Fig. 1. Main and associated eddy covariance tower sites of CarboEurope IP, names indicate verification sites with intensive soil analyses (taken from Schrumpf et al., 2008).

Soil samples were taken between March and December 2004. Cropland sites were sampled after harvest. The Carlow site was not tilled then, the Gebesee site was grubbed, and the Grignon site is partly under reduced tillage (the other half was managed as no-till system) before sampling. A corer with an inner diameter of 8.3 and $8.7 \mathrm{~cm}$ (Eijkelkamp Agrisearch Equipment BV, Giesbeek, The Netherlands) was used for mineral soil sampling. The core was driven into soil with a motor hammer (Cobra Combi, Atlas Copco AB, Nacka, Sweden). The depth of the borehole and the length of the extracted core were measured and compared for estimation of soil compaction during coring. Except for five cores at Hesse and Sor $\varnothing$, where the core length was 5 to $10 \mathrm{~cm}$ less than the depth of the borehole (probably because of watersaturated B horizons), maximum compaction was less than $3 \%$. Before coring, the vegetation cover at the grassland sites was removed from within a $25 \mathrm{~cm} \times 25 \mathrm{~cm}$ frame by cutting with a knife. The same frame was used to collect litter layer samples at the forest sites. The targeted sampling depth for mineral soils was $60 \mathrm{~cm}$. Whenever not possible to reach that depth, a second attempt was made at $1 \mathrm{~m}$ distance. If necessary, the procedure was repeated a third time and then the longest of the three cores was used for analyses. Coring problems occurred at sites with stony subsoils, i.e., Hainich, Soroe, Carlow, Laqueuille, and at Le Bray, where an indurated subsoil layer was present. Soil cores were visually characterized, photographed and then sectioned into segments $(0-5,5-10,10-20,20-30,30-40,40-50$, and 50$60 \mathrm{~cm}$ ). The high stone content at two selected coniferous forest sites impeded the application of a soil corer, so that 15 soil monoliths $(25 \mathrm{~cm} \times 25 \mathrm{~cm})$ were carefully excavated to a depth of $50 \mathrm{~cm}(0-10,10-30$, and $30-50 \mathrm{~cm}$ steps $)$ at Wetzstein, and 80 soil monoliths at Norunda $(0-5$ and $5-10 \mathrm{~cm})$ instead. To account for the volume and mass of stones at the boundary of the monoliths, stones reaching into the extracted soil sample were marked at the stone surface before taken out of the wall. As it was not possible to split the stones, the part protruding into the sample monolith was replaced as good as possible by smaller stones of equivalent volume. Large boulders from glacial till could not be removed from the monoliths at Norunda. To account for their contribution, the volume of the excavated soil pit was determined by volume replacement with sand of a grain size of $0.063-0.125 \mathrm{~mm}$. At 12 sampling points, organic layer was directly covering large boulders, and at 8 other places, small peaty areas occurred. These sampling points were not included in this analysis.

\subsection{Sample preparation and analyses}

Soil samples were stored at $4{ }^{\circ} \mathrm{C}$ prior to processing. Coarse stones of a diameter $>4 \mathrm{~mm}$ and roots of a diameter $>1 \mathrm{~mm}$, including side roots, were removed from the samples prior to drying at $40^{\circ} \mathrm{C}$. Stone and root samples were air dried separately. Then, soil samples were sieved to $<2 \mathrm{~mm}$. Particles $>2 \mathrm{~mm}$ were combined with the coarse stones. The dry weights of roots and the combined stone fractions were determined. Densities of stones from the Wetzstein and Norunda sites were determined by water displacement to calculate bulk densities of the soils.

Total $\mathrm{C}$ and $\mathrm{N}$ concentrations in $<2 \mathrm{~mm}$ soil separates were determined after dry combustion (VarioMax $\mathrm{CH}$ analyzer, Elementar Analysensysteme $\mathrm{GmbH}$, Hanau, Germany). In soils free of carbonates, the total $\mathrm{C}$ represents organic C. Five of the study sites had carbonates. Here, OC was determined as the difference between total and carbonate-C. At the sites Hainich, Gebesee and Carlow, the carbonate-C content was determined after dry combustion of the samples in a muffle furnace at $450^{\circ} \mathrm{C}$ for $16 \mathrm{~h}$. For Bugac and Sor $\varnothing$, the carbonate- $\mathrm{C}$ content was analyzed by determining the evolution of $\mathrm{CO}_{2}$ upon treatment with phosphoric acid (C-MAT 550, Ströhlein GmbH, Viersen, Germany). This was especially important at the Bugac site, where carbonates could not be determined accurately by the dry combustion method due to the presence of fossil/charred C. Organic layer samples were dried at $70^{\circ} \mathrm{C}$, shredded, and a subsample further homogenized using a ball mill. Total $\mathrm{C}$ and $\mathrm{N}$ concentrations were determined using an elemental analyzer 
Table 2. Average OC stocks (av.) for different soil layers, their standard deviation (s.d.), coefficient of variation (CV), and minimum detectable difference (MDD, $n=100$ samples, $\alpha=0.05, \beta=0.2$; value in parenthesis is percentage of average stock). Left-hand data refer to definite soil volumes, as the soil samples were taken by depth increments. Values to the right were calculated for definite soil masses (average soil mass of each site and layer) per unit area.

\begin{tabular}{|c|c|c|c|c|c|c|c|c|c|}
\hline \multicolumn{5}{|c|}{ OC stocks per unit area by volume } & \multicolumn{5}{|c|}{ OC stocks per unit area by equivalent soil masses } \\
\hline \multirow[b]{2}{*}{$\begin{array}{l}\text { Soil layer } \\
\text { Depth (m) }\end{array}$} & \multicolumn{4}{|c|}{ OC stocks } & \multirow[b]{2}{*}{$\begin{array}{l}\text { Soil layer } \\
(\mathrm{g} \text { soil m} \\
\end{array}$} & \multicolumn{4}{|c|}{ OC stocks } \\
\hline & $\begin{array}{l}\text { av. } \\
(\mathrm{g} \mathrm{OC} \mathrm{m}\end{array}$ & $\begin{array}{l}\text { s.d. } \\
\left.a^{-2}\right)\end{array}$ & $\begin{array}{l}\mathrm{CV} \\
\%\end{array}$ & $\begin{array}{l}\mathrm{MDD} \\
\left(\mathrm{g} \mathrm{OC}^{-2}\right)\end{array}$ & & $\begin{array}{l}\text { av. } \\
\text { (g OC n }\end{array}$ & $\begin{array}{l}\text { s.d. } \\
\left.\mathrm{n}^{-2}\right)\end{array}$ & $\begin{array}{l}\mathrm{CV} \\
\%\end{array}$ & $\begin{array}{l}\text { MDD } \\
\left(\mathrm{g} \mathrm{OC} \mathrm{m}^{-2}\right)\end{array}$ \\
\hline \multicolumn{10}{|c|}{ Hainich, Germany, deciduous forest, $51^{\circ} 04^{\prime} \mathrm{N}, 10^{\circ} 27^{\prime} \mathrm{E}, 800 \mathrm{~mm}$, Eutric Cambisol } \\
\hline Oi & 365 & 136 & 37 & $44(12)$ & & & & & \\
\hline Oe & 213 & 115 & 54 & 38 (19) & & & & & \\
\hline $0-0.05$ & 2332 & 412 & 18 & $133(6)$ & $0-39$ & 2313 & 455 & 20 & 146 \\
\hline $0-0.10$ & 4152 & 689 & 17 & $224(5)$ & $0-88$ & 4137 & 785 & 19 & 255 \\
\hline $0-0.30$ & 8821 & 1224 & 14 & $395(5)$ & $0-332$ & 8785 & 1383 & 16 & 448 \\
\hline $0-0.60$ & 11754 & 1926 & 16 & $626(5)$ & & & & & \\
\hline \multicolumn{10}{|c|}{ Hesse, France, deciduous forest, $48^{\circ} 40^{\prime} \mathrm{N}, 07^{\circ} 05^{\prime} \mathrm{E}, 820 \mathrm{~mm}$, Stagnic Luvisol } \\
\hline Oi & 287 & 75 & 26 & $21(7)$ & & & & & \\
\hline Oe & 300 & 230 & 77 & 75 (27) & & & & & \\
\hline $0-0.05$ & 1161 & 277 & 24 & $91(8)$ & $0-42$ & 1154 & 327 & 28 & 107 \\
\hline $0-0.10$ & 2104 & 387 & 18 & $126(6)$ & $0-96$ & 2110 & 490 & 23 & 159 \\
\hline $0-0.30$ & 4873 & 787 & 16 & $253(5)$ & $0-338$ & 4868 & 932 & 19 & 302 \\
\hline $0-0.60$ & 6687 & 1220 & 18 & $395(6)$ & & & & & \\
\hline \multicolumn{10}{|c|}{ Soroe, Denmark, deciduous forest, $55^{\circ} 29^{\prime} \mathrm{N}, 11^{\circ} 38^{\prime} \mathrm{E}, 660 \mathrm{~mm}$, Gleyic Cambisol } \\
\hline Oi & 274 & 81 & 29 & $26(11)$ & & & & & \\
\hline Oe & 350 & 200 & 57 & $65(20)$ & & & & & \\
\hline $0-0.05$ & 1929 & 490 & 25 & $159(8)$ & 0-39 & 1930 & 614 & 32 & 198 \\
\hline $0-0.10$ & 3674 & 1034 & 28 & $290(8)$ & $0-88$ & 3662 & 1179 & 32 & 382 \\
\hline $0-0.30$ & 7788 & 2637 & 34 & 739 (9) & $0-331$ & 7812 & 2997 & 38 & 972 \\
\hline $0-0.60$ & 9254 & 2809 & 30 & 787 (9) & & & & & \\
\hline \multicolumn{10}{|c|}{ LeBray, France, coniferous forest, $44^{\circ} 43^{\prime} \mathrm{N}, 0^{\circ} 46^{\prime} \mathrm{E}, 900 \mathrm{~mm}$, Anthric Ortsteinic Podzol } \\
\hline $\mathrm{Oi}$ & 633 & 364 & 58 & $118(19)$ & & & & & \\
\hline $\mathrm{Oe}+\mathrm{Oa}$ & 2430 & 1387 & 57 & 454 (19) & & & & & \\
\hline $0-0.05$ & 1708 & 464 & 27 & $150(9)$ & $0-44$ & 1718 & 549 & 32 & 178 \\
\hline $0-0.10$ & 3358 & 888 & 26 & $288(9)$ & 0-98 & 3376 & 1060 & 31 & 344 \\
\hline $0-0.30$ & 9917 & 2366 & 24 & 767 (8) & $0-345$ & 9881 & 2692 & 27 & 873 \\
\hline $0-0.60$ & 15072 & 4303 & 29 & 1395 (9) & & & & & \\
\hline \multicolumn{10}{|c|}{ Norunda, Sweden, coniferous forest, $60^{\circ} 5^{\prime} \mathrm{N}, 17^{\circ} 29^{\prime} \mathrm{E}, 527 \mathrm{~mm}$, Haplic Podzol } \\
\hline $\mathrm{Oi}$ & 450 & 132 & 29 & $\begin{array}{l}43(10) / \\
48(11)^{\mathrm{a}}\end{array}$ & & & & & \\
\hline $\mathrm{Oe}+\mathrm{Oa}$ & 3267 & 2005 & 61 & $\begin{array}{l}650(20) / \\
727(22)^{\mathrm{a}}\end{array}$ & & & & & \\
\hline $0-0.10$ & 1672 & 831 & 50 & $\begin{array}{l}269(16) / \\
301(18)^{\mathrm{a}}\end{array}$ & & & & & \\
\hline
\end{tabular}


Table 2. Continued.

\begin{tabular}{|c|c|c|c|c|c|c|c|c|c|}
\hline \multicolumn{5}{|c|}{ OC stocks per unit area by volume } & \multicolumn{5}{|c|}{ OC stocks per unit area by equivalent soil masses } \\
\hline \multirow[b]{2}{*}{$\begin{array}{l}\text { Soil layer } \\
\text { Depth (m) }\end{array}$} & \multicolumn{4}{|c|}{ OC stocks } & \multirow[b]{2}{*}{$\begin{array}{l}\text { Soil layer } \\
\left(\mathrm{g} \text { soil } \mathrm{m}^{-2}\right)\end{array}$} & \multicolumn{4}{|c|}{ OC stocks } \\
\hline & $\begin{array}{l}\text { av. } \\
(\mathrm{g} \mathrm{OC} \mathrm{m}\end{array}$ & $\begin{array}{l}\text { s.d. } \\
\left.a^{-2}\right)\end{array}$ & $\begin{array}{l}\mathrm{CV} \\
\%\end{array}$ & $\begin{array}{l}\operatorname{MDD} \\
\left(\mathrm{g} \mathrm{OC} \mathrm{m}^{-2}\right)\end{array}$ & & $\begin{array}{l}\text { av. } \\
\text { (g OC m }\end{array}$ & $\begin{array}{l}\text { s.d. } \\
-2)\end{array}$ & $\begin{array}{l}\mathrm{CV} \\
\%\end{array}$ & $\begin{array}{l}\text { MDD } \\
\left(\mathrm{g} \mathrm{OC} \mathrm{m}^{-2}\right)\end{array}$ \\
\hline \multicolumn{10}{|c|}{ Wetzstein, Germany, coniferous forest, $50^{\circ} 27^{\prime} \mathrm{N}, 11^{\circ} 27^{\prime} \mathrm{E}, 840 \mathrm{~mm}$, Cambic Podzol } \\
\hline Oi & 619 & 328 & 53 & $\begin{array}{l}106(17) / \\
275(44)^{b}\end{array}$ & & & & & \\
\hline $\mathrm{Oe}+\mathrm{Oa}$ & 7345 & 2358 & 32 & $\begin{array}{l}764(10) / \\
1974(27)^{b}\end{array}$ & & & & & \\
\hline $0-0.10$ & 2290 & 864 & 38 & $\begin{array}{l}280(12) / \\
723(32)^{b}\end{array}$ & & & & & \\
\hline $0-0.30$ & 5924 & 1546 & 26 & $\begin{array}{l}501(8) / \\
1294(22)^{\mathrm{b}}\end{array}$ & & & & & \\
\hline $0-0.50$ & 8275 & 1708 & 21 & $\begin{array}{l}554(7) / \\
1430(17)^{b}\end{array}$ & & & & & \\
\hline \multicolumn{10}{|c|}{ Laqueuille, France, grassland, $45^{\circ} 38^{\prime} \mathrm{N}, 02^{\circ} 44^{\prime} \mathrm{E}, 1313 \mathrm{~mm}$, Umbric Andosol } \\
\hline $0-0.05$ & 3027 & 455 & 15 & $146(5)$ & $0-23$ & 3009 & 292 & 10 & 94 \\
\hline $0-0.10$ & 6467 & 632 & 10 & $205(3)$ & $0-58$ & 6415 & 593 & 9 & 192 \\
\hline $0-0.30$ & 15713 & 1254 & 8 & $407(3)$ & $0-215$ & 15663 & 1362 & 9 & 439 \\
\hline $0-0.60$ & 22907 & 2525 & 11 & $817(4)$ & & & & & \\
\hline \multicolumn{10}{|c|}{ Bugac, Hungary, grassland, $46.8^{\circ} \mathrm{N}, 18.9^{\circ} \mathrm{E}, 500 \mathrm{~mm}$, Eutric Arenosol } \\
\hline $0-0.05$ & 2870 & 488 & 17 & $158(6)$ & $0-40$ & 2852 & 666 & 23 & 217 \\
\hline $0-0.10$ & 5255 & 834 & 16 & $270(5)$ & $0-101$ & 5182 & 1026 & 20 & 333 \\
\hline $0-0.30$ & 9232 & 1552 & 17 & $503(5)$ & $0-414$ & 9228 & 1629 & 18 & 528 \\
\hline $0-0.60$ & 12332 & 2330 & 19 & $755(6)$ & & & & & \\
\hline \multicolumn{10}{|c|}{ Easter Bush, UK, grassland, 5552’ N, $3^{\circ} 10^{\prime} \mathrm{W}, 890 \mathrm{~mm}$, Stagnic Cambisol } \\
\hline $0-0.05$ & 2027 & 288 & 14 & $93(5)$ & $0-46$ & 2003 & 270 & 14 & 88 \\
\hline $0-0.10$ & 3707 & 440 & 12 & $143(4)$ & 0-107 & 3701 & 427 & 12 & 138 \\
\hline $0-0.30$ & 9260 & 1014 & 11 & 329 (4) & $0-376$ & 9168 & 1015 & 11 & 329 \\
\hline $0-0.60$ & 12283 & 1473 & 12 & $478(4)$ & & & & & \\
\hline \multicolumn{10}{|c|}{ Carlow, Ireland, cropland, $52^{\circ} 51^{\prime} \mathrm{N}, 6^{\circ} 54^{\prime} \mathrm{W}, 804 \mathrm{~mm}$, Eutric Cambisol } \\
\hline $0-0.05$ & 972 & 249 & 26 & $81(8)$ & $0-43$ & 978 & 163 & 17 & 52 \\
\hline $0-0.10$ & 1986 & 410 & 21 & $133(7)$ & $0-88$ & 2012 & 326 & 16 & 108 \\
\hline $0-0.30$ & 6036 & 852 & 14 & $276(5)$ & $0-286$ & 5835 & 866 & 15 & 278 \\
\hline $0-0.60$ & 7412 & 1421 & 19 & $461(6)$ & & & & & \\
\hline \multicolumn{10}{|c|}{ Gebesee, Germany, cropland, 51 $06^{\prime} \mathrm{N}, 10^{\circ} 55^{\prime} \mathrm{E}, 470 \mathrm{~mm}$, Haplic Phaeozem } \\
\hline $0-0.05$ & 1277 & 157 & 12 & $51(4)$ & $0-54$ & 1287 & 93 & 7 & 30 \\
\hline $0-0.10$ & 2756 & 241 & 9 & $78(3)$ & $0-124$ & 2784 & 133 & 5 & 43 \\
\hline $0-0.30$ & 8650 & 473 & 5 & $153(2)$ & $0-404$ & 8690 & 354 & 4 & 115 \\
\hline $0-0.60$ & 13089 & 1394 & 11 & $452(3)$ & & & & & \\
\hline \multicolumn{10}{|c|}{ Grignon, France, cropland, $48^{\circ} 51^{\prime} \mathrm{N}, 1^{\circ} 58^{\prime} \mathrm{E}, 700 \mathrm{~mm}$, Eutric Cambisol } \\
\hline $0-0.05$ & 1363 & 247 & 18 & $80(6)$ & $0-64$ & 1351 & 150 & 11 & 49 \\
\hline $0-0.10$ & 2788 & 324 & 12 & $105(4)$ & $0-137$ & 2780 & 230 & 8 & 75 \\
\hline $0-0.30$ & 8241 & 812 & 10 & $263(3)$ & $0-440$ & 8255 & 751 & 9 & 243 \\
\hline $0-0.60$ & 11140 & 1222 & 11 & $396(4)$ & & & & & \\
\hline
\end{tabular}

${ }^{a} \operatorname{MDD}$ for $n=80$

$\mathrm{b}$ MDD for $n=15$ 
(Vario EL II, Elementar Analysensysteme GmbH, Hanau, Germany).

\subsection{Calculations and statistical analyses}

Organic carbon stocks (Eq. 1) for fixed soil volumes of seven soil layers (i) were calculated based on bulk density (BD, Eq. 2), the relative contribution of fine earth material (soil $<2 \mathrm{~mm}$ ) to total soil mass (FE content), layer thickness, and $\mathrm{OC}$ concentration.

$$
\begin{aligned}
& \text { OC stock }{ }_{i}\left(\mathrm{~g} \mathrm{~m}^{-2}\right)=\mathrm{OC} \text { concentration }{ }_{i}\left[\mathrm{~g} \mathrm{~kg}^{-1}\right] \\
& \text { - } \mathrm{BD}_{i}\left[\mathrm{~g} \mathrm{~cm}^{-3}\right] \cdot \text { layer thickness }{ }_{i}[\mathrm{~cm}] \cdot \mathrm{FE} \text { content }_{i} \cdot 10
\end{aligned}
$$

$\mathrm{BD}\left[\mathrm{g} \mathrm{cm}^{-3}\right]=\frac{\text { total sample weight }[\mathrm{g}]}{\text { sample volume }\left[\mathrm{cm}^{3}\right]}$

In order to determine sources of uncertainties in assessment of SOC stocks, we used the error propagation formula based on a linear Taylor series expansion as described by Goidts et al. (2009a). Soil depth was fixed in our study so that it will not directly be addressed as error source. Errors associated with incorrect cuttings of core segments will mostly be included in uncertainties of $\mathrm{BD}$ and FE contents. The total variance of OC stocks for each site and soil layer can then be apportioned into the following terms including variances of single factors and covariances between factors:

$$
\begin{aligned}
& \operatorname{Var}(\mathrm{OC} \text { stock })=(\mathrm{OC} \text { stock })^{2} \cdot\left(\frac{\left(\sigma_{\mathrm{OC}}\right)^{2}}{(\mathrm{OC})^{2}}+\frac{\left(\sigma_{\mathrm{BD}}\right)^{2}}{(\mathrm{BD})^{2}}+\frac{\left(\sigma_{\mathrm{FE}}\right)^{2}}{(\mathrm{FE})^{2}}\right. \\
&\left.+2 \cdot \frac{\sigma_{\mathrm{OC}-\mathrm{BD}}}{\mathrm{OC} \cdot \mathrm{BD}}+2 \cdot \frac{\sigma_{\mathrm{OC}-\mathrm{FE}}}{\mathrm{OC} \cdot \mathrm{FE}}+2 \cdot \frac{\sigma_{\mathrm{BD}-\mathrm{FE}}}{\mathrm{BD} \cdot \mathrm{FE}}\right)
\end{aligned}
$$

Here, $\sigma_{\mathrm{OC}}, \sigma_{\mathrm{BD}}$ and $\sigma_{\mathrm{FE}}$ denote the standard deviations of $\mathrm{OC}$ concentration (OC), bulk density (BD) and fine earth content $(\mathrm{FE})$; and $\sigma_{\mathrm{OC}-\mathrm{BD}}, \sigma_{\mathrm{OC}-\mathrm{FE}}$ and $\sigma_{\mathrm{BD}-\mathrm{FE}}$ the covariances between the respective factors. Standard deviations and covariances were directly estimated from the measured data sets for individual sites and depth layers. In order to calculate the relative contribution of each error source including covariances to the total variance, we multiplied each term of the sum in Eq. (3) with the square of respective OC stocks. As some of the covariance terms had a negative sign, we used the sum the absolute values of each term as $100 \%$ for the calculation of relative contributions. In addition to OC stocks based on fixed soil volumes, OC stocks were calculated for equivalent soil masses per area as in Ellert and Bettany (1995). This was done first for predefined fine earth masses $(<2 \mathrm{~mm})$ of 100 , 300 and $600 \mathrm{~kg} \mathrm{~m}^{-2}$ for all sites and then for average fine earth masses per analyzed soil layer for each site separately. As we did not measure the $\mathrm{C}$ content of the stones, we used the fine earth mass instead of the total soil mass as reference.

Pedotransfer functions (PTF) are used to estimate BD where not measured (e.g. Bellamy et al., 2005; Lettens et al., 2005a, b). Estimated bulk densities (BDp) are derived from the negative relation between $\mathrm{OC}$ concentrations and BD. For our data set (excluding the stone-rich sites Norunda and Wetzstein), exponential functions gave best fit (Eq. 4, with $\beta_{0}, \beta_{1}$, and $\varepsilon$ being factors of the function). In many soil surveys, PTF are applied to calculate OC stocks without accounting for the uncertainty introduced by the estimation of BD. This error includes the prediction error of the PTF itself plus the uncertainty of the determination of the OC concentration as the independent variable in Eq. (4). Thus, we calculated the error associated with PTF-based estimates of BDp by Eq. (5):

$\mathrm{BDp}=\beta_{0} \cdot \exp \left(\beta_{1} \cdot \mathrm{OC}\right)+\varepsilon$

$\sigma_{\mathrm{BDp}}^{2}=(\text { residual standard error of "Eq. } 4 \text { ") })^{2}+\beta_{0}^{2} \cdot \beta_{1}^{2}$

$$
\cdot \exp \left(2 \cdot \beta_{1} \cdot \mathrm{OC}\right) \cdot \sigma_{\mathrm{OC}^{2}}
$$

The variance of OC stocks calculated with PTF-based estimates of $\mathrm{BDp}$ was then calculated according to the following two equations (Eqs. 6, 7). The variance of OC stocks based on estimated BD without accounting for the associated error $\left(\operatorname{Var}\left(\mathrm{OCstock}_{\mathrm{ped}}\right)_{\mathrm{se}}\right)$ was determined by calculat-

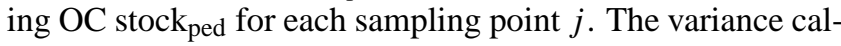
culated by Eq. (7) includes the uncertainty of BDp estimation $\left(\operatorname{Var}\left(\mathrm{OC} \text { stock }_{\mathrm{ped}}\right)_{\mathrm{ep}}\right)$ :

$$
\begin{aligned}
& \operatorname{Var}\left(\text { OCstock }_{\text {ped }}\right)_{\mathrm{se}}=\frac{1}{\mathrm{n}-1} \sum_{\mathrm{j}=1}^{\mathrm{n}} \\
& \quad\left(\mathrm{OCstock}_{\mathrm{ped}}(\mathrm{j})-\mathrm{av} \cdot\left(\mathrm{OCstock}_{\mathrm{ped}}\right)\right)^{2} \\
& \operatorname{Var}\left(\mathrm{OCstock}_{\mathrm{ped}}\right)_{\mathrm{ep}}=\left(\mathrm{OC} \text { stock }_{\mathrm{ped}}\right)^{2} \cdot\left(\frac{\left(\sigma_{\mathrm{OC}}\right)^{2}}{(\mathrm{OC})^{2}}+\frac{\left(\sigma_{\mathrm{BDp}}\right)^{2}}{(\mathrm{BDp})^{2}}\right. \\
& \left.+\frac{\left(\sigma_{\mathrm{FE}}\right)^{2}}{(\mathrm{FE})^{2}}+2 \cdot \frac{\sigma_{\mathrm{OC}-\mathrm{BDp}}}{\mathrm{OC} \cdot \mathrm{BDp}}+2 \cdot \frac{\sigma_{\mathrm{OC}-\mathrm{FE}}}{\mathrm{OC} \cdot \mathrm{FE}}+2 \cdot \frac{\sigma_{\mathrm{BDp}-\mathrm{FE}}}{\mathrm{BDp} \cdot \mathrm{FE}}\right)
\end{aligned}
$$

where OCstock $\mathrm{ped}_{\text {is }}$ the OC stock based on estimated BDp. Calculations were done for all $\mathrm{n}$ samples of each site and each soil depth individually. Covariances between $\mathrm{BDp}$ and OC or FE were calculated for each site and soil depth based on BDp values and measured OC concentrations and FE contents. Note, when BD is determined using PTF usually no measured values of $\mathrm{FE}$ content are available, i.e., additional errors associated with the stone content may apply.

As the application of pedotransfer functions can cause biases in the determined OC stocks, we also calculated the mean error (ME) and the root mean square errors (RMSE) of estimated OC stocks for each site and soil layer according to Eqs. (8) and (9):

$$
\begin{aligned}
& \mathrm{ME}=\frac{1}{\mathrm{n}} \sum_{\mathrm{j}=1}^{\mathrm{n}}\left(\mathrm{OCstock}_{(\mathrm{j})}-\mathrm{OCstock}_{\text {ped }(\mathrm{j})}\right) \\
& \mathrm{RMSE}=\sqrt{\frac{1}{\mathrm{n}} \sum_{\mathrm{j}=1}^{\mathrm{n}}\left(\mathrm{OCstock}_{(\mathrm{j})}-\text { OCstock }_{\text {ped }(\mathrm{j})}\right)^{2}}
\end{aligned}
$$




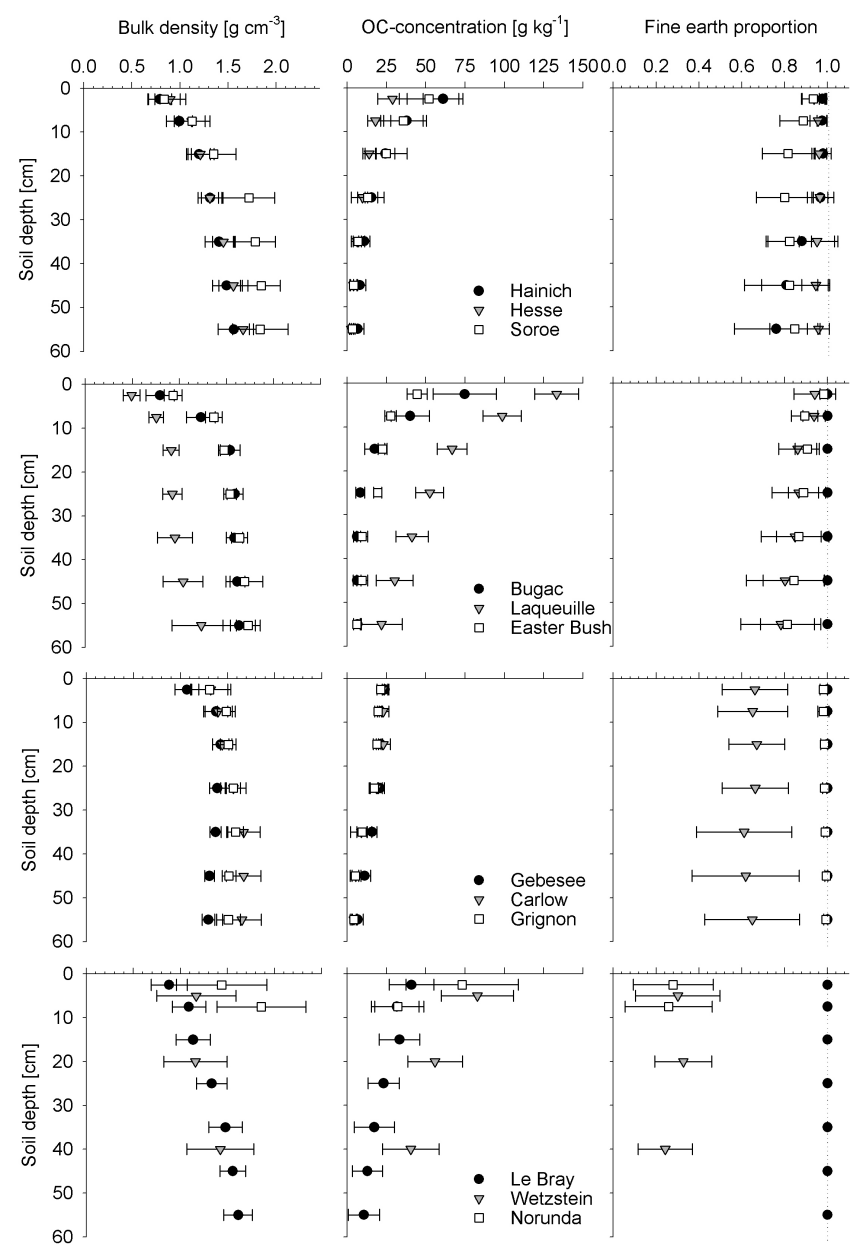

Fig. 2. Depth distribution of average soil bulk densities (BD), OC concentrations, and the fine earth contents ( \pm one standard deviation) at the study sites.

Measured OC stock is treated here as true value though it is also associated with an analytical error, which can bias results. The minimum detectable difference (MDD) of OC stocks for different sites and soil layers was determined for a sample size of 100 using a two-sided paired sample t-test, with $\alpha=0.05$ and $\beta=0.10$. Paired re-sampling and constant variability of OC stocks for the second sampling period were assumed. Calculations of MDD were performed with the program PASS (Hintze, 2001), nonlinear regression analysis using the program SPSS 16.0 (SPSS Inc.).

\section{Results}

\subsection{Soil characteristics}

Site-average bulk densities (BD) ranged between 0.49 and $1.44 \mathrm{~g} \mathrm{~cm}^{-3}$ in the $0-5 \mathrm{~cm}$ layer and increased with soil depth to values between 1.23 and $1.83 \mathrm{~g} \mathrm{~cm}^{-3}$ in the $50-60 \mathrm{~cm}$ layer (Fig. 2). Cropland sites had highest bulk densities of

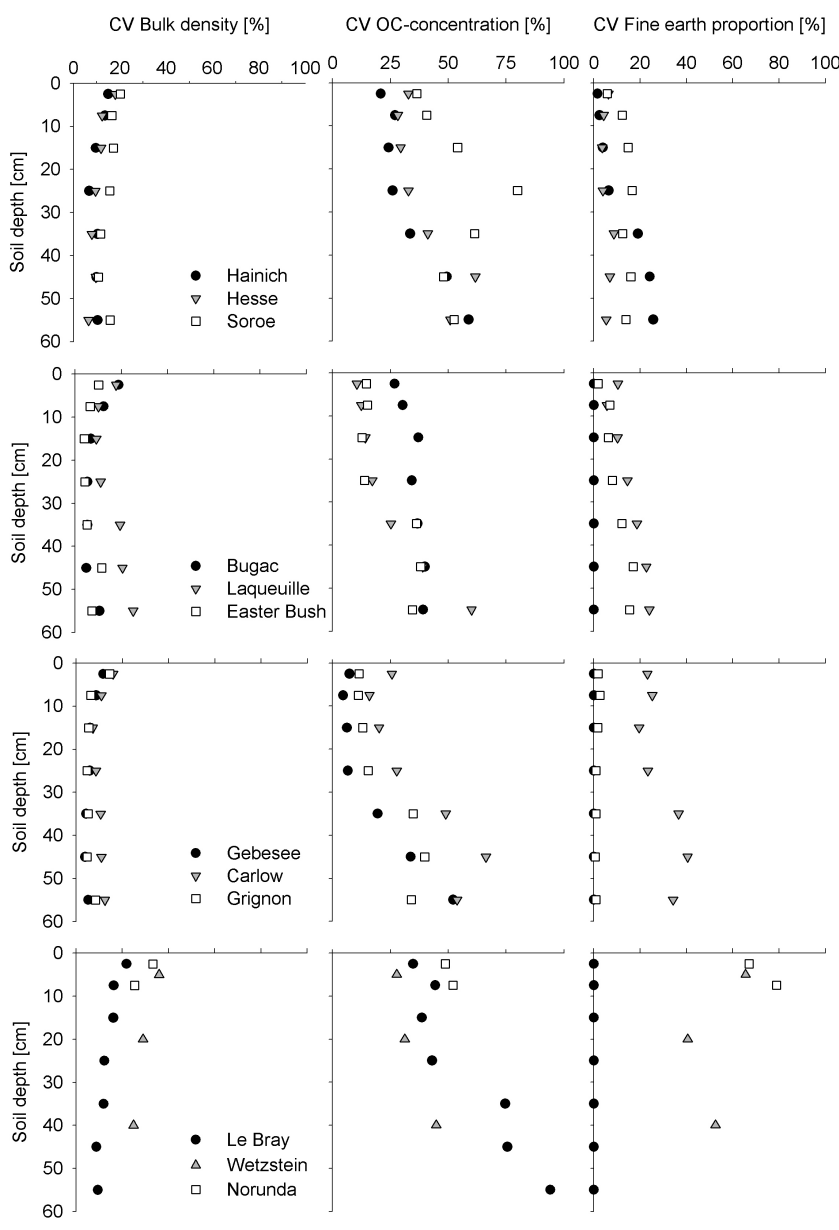

Fig. 3. Coefficients of variation for soil bulk densities, OC concentrations, and the fine earth contents at different soil depths at the study sites.

all land use types in the upper $20 \mathrm{~cm}$ of the mineral soil (excluding stone rich sites) and showed little variation with depth. High stone contents raised BD at Norunda and Wetzstein, though a low BD of the fine earth fraction at Wetzstein counterbalanced some of the effect. The coefficient of variation $(\mathrm{CV})$ was calculated as a relative measure for within-site variability of soil properties (Fig. 3). It ranged between 4 and $36 \%$ across all sites and soil depths for BD.

Organic $\mathrm{C}$ concentrations declined from $21-133 \mathrm{~g} \mathrm{~kg}^{-1}$ at the $0-5 \mathrm{~cm}$ layer to $3-22 \mathrm{~g} \mathrm{~kg}^{-1}$ at the $50-60 \mathrm{~cm}$ layer across all sites. The OC concentrations of the three cropland sites were remarkably similar and showed the typical OC depth distribution of soils with regular tillage, with homogeneous concentrations throughout the plow layer $(0-30 \mathrm{~cm}$, Fig. 2). At the grassland site Easter Bush, plowing $10 \mathrm{yr}$ ago was still visible in the depth distribution of $\mathrm{OC}$ concentrations. The $\mathrm{CV}$ of OC concentrations was usually larger than that of BD and ranged between $21-49 \%$ in the $0-5 \mathrm{~cm}$ layer of forest sites, $10-27 \%$ at grassland sites, and $7-17 \%$ at croplands. 


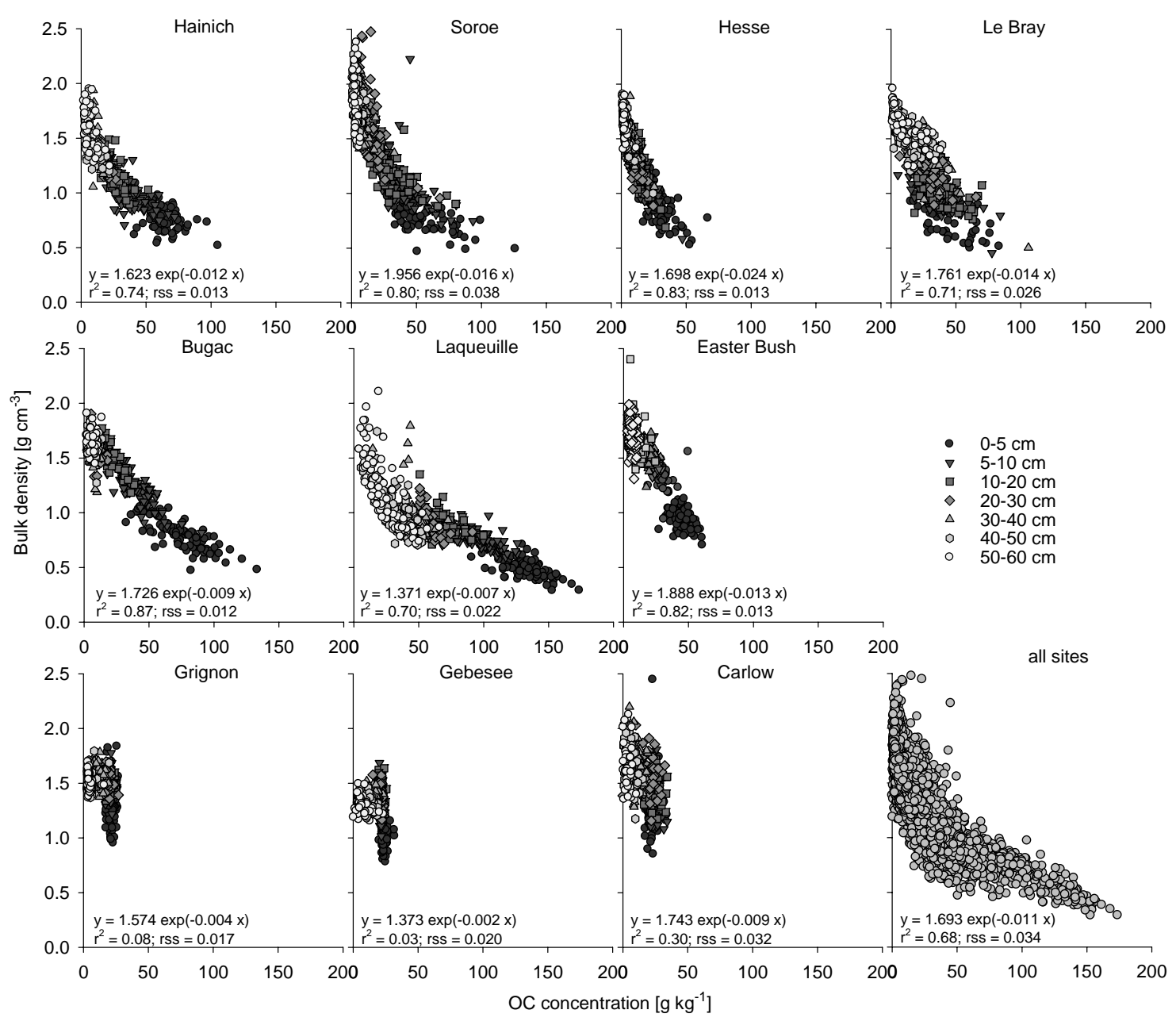

Fig. 4. Relation between OC concentration and bulk density (BD) at different sites and across all sites. Samples from all soil depths are included in the graphs. Equations are the result of a nonlinear regression analyses between OC concentrations and BD $\left(r^{2}\right.$ : coefficient of determination; rss: residual sum of squares).

For most sites, $\mathrm{CV}$ of OC concentrations increased with soil depth (Fig. 3).

At all grassland and forest sites, BD was significantly negatively correlated with OC concentrations (Fig. 4). Exponential functions fitted reasonably well data of all samples of each site as the decrease in BD with increasing OC concentrations was more pronounced at $\mathrm{OC}$ concentrations less than about $50 \mathrm{~g} \mathrm{~kg}^{-1}$ and less intensive at higher OC concentrations. Different curves revealed site-specific differences in the relation between BD and $\mathrm{OC}$ concentrations. For the cropland sites, there was almost no relation between BD and OC concentrations when applied to individual layers. The low BDs in the $0-5 \mathrm{~cm}$ layer at Grignon and Gebesee, the recently tilled sites, cannot be explained by OC concentrations.

The soils at Bugac, Le Bray, Gebesee and Grignon were almost free of stones while the other sites contained variable amounts of coarse particles (Fig. 2). At Wetzstein and Norunda, where soil pits were analyzed, fine earth mass only accounted on average for 24 to $33 \%$ of the total soil mass in all soil layers while it was 61 to $100 \%$ at the other sites. The $\mathrm{CV}$ of the fine earth proportion ranged between 2 and $79 \%$ across sites and soil depths and usually increased with larger stone contents.

Mineral soil OC stocks to $60 \mathrm{~cm}$ depth averaged to $12193 \pm 4559 \mathrm{~g} \mathrm{~m}^{-2}$ across sites. Largest OC stocks occurred at the grassland site Laqueuille $\left(22907 \mathrm{~g} \mathrm{~m}^{-2}\right)$ and the coniferous forest Le Bray $\left(15072 \mathrm{~g} \mathrm{~m}^{-2}\right.$, plus $3063 \mathrm{~g} \mathrm{~m}^{-2}$ in the litter layers), smallest at Hesse $\left(6687 \mathrm{~g} \mathrm{~m}^{-2}\right)$ and Carlow $\left(7412 \mathrm{~g} \mathrm{~m}^{-2}\right.$; Table 2$)$. Litter layers held $6-9 \%$ to total stocks at the deciduous forests, but $17 \%$ and $49 \%$ at the coniferous forests Le Bray and Wetzstein, respectively. The depth distributions of OC stocks in the mineral soil closely resembled those of the OC concentrations. Across sites, $75 \%$ of OC stocks of mineral soils were in the upper $30 \mathrm{~cm}$ and $25 \%$ between 30 and $60 \mathrm{~cm}$ soil depth.

The negative correlation between $\mathrm{OC}$ concentration and bulk density (Fig. 4) seemed to cause the lower CV of soil OC stocks than of OC concentrations in the $0-5 \mathrm{~cm}$ layers of 


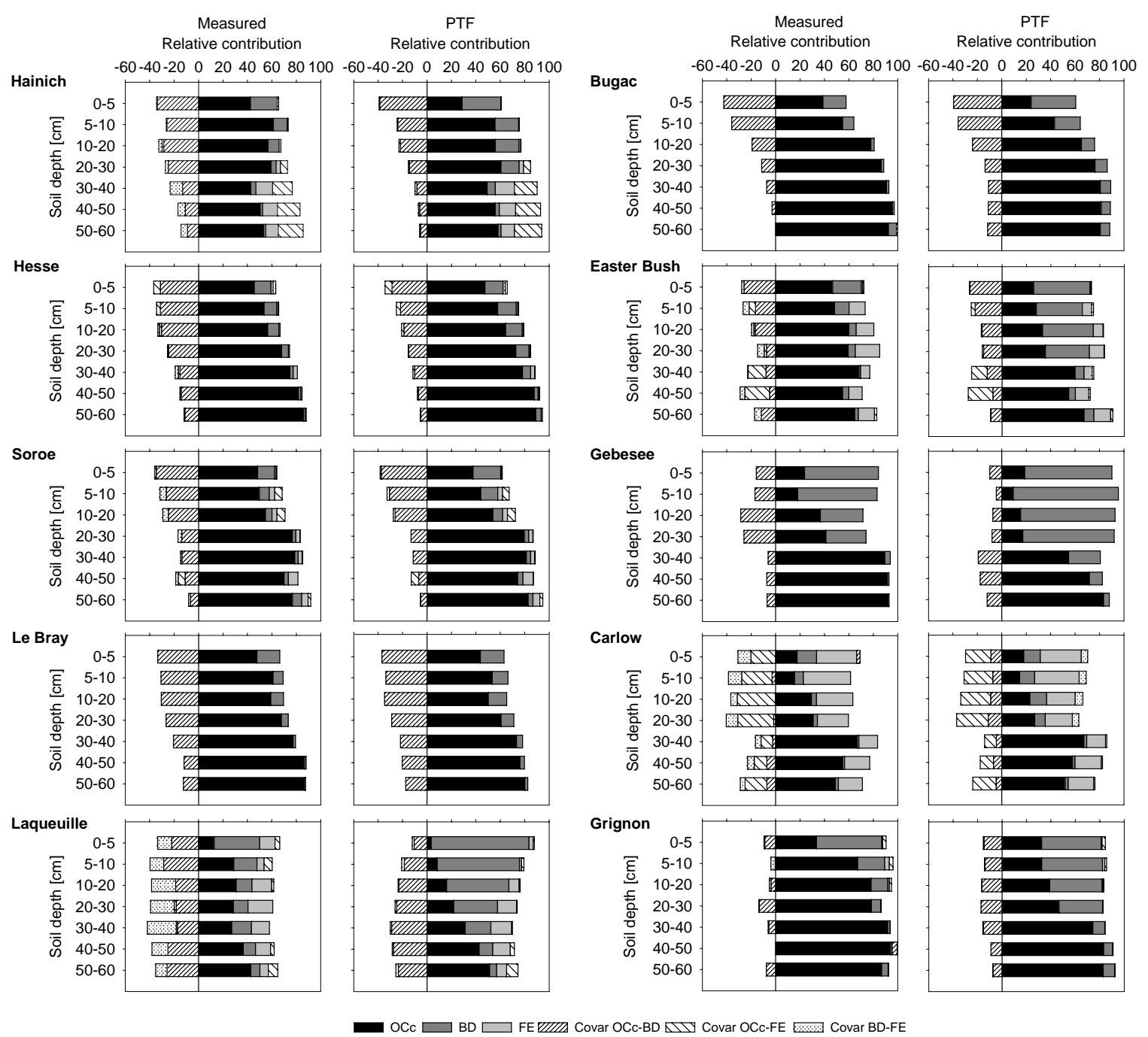

Fig. 5. Relative contribution of OC concentration (OCc), bulk density (BD), fine earth content (FE), and the covariances between OCc and $\mathrm{BD}, \mathrm{OCc}$ and $\mathrm{FE}$, and $\mathrm{BD}$ and $\mathrm{FE}$ to the variance of $\mathrm{OC}$ stocks (soil depth in $\mathrm{cm}$, relative contribution in \%).

forests (18-27\%) and grasslands (14-17\%) (Table 2, Fig. 2). The CV decreased with increasing soil volume considered (Table 2). For the deciduous forest at Hesse, the CV for the $0-5 \mathrm{~cm}$ layer was $24 \%, 18 \%$ for the $0-10 \mathrm{~cm}$ layer, and $16 \%$ for the $0-30 \mathrm{~cm}$ layer; at the grassland at Laqueuille the respective CVs were 15,10 , and $8 \%$. Still, the CV for the $0-60 \mathrm{~cm}$ layer was often higher than for the $0-30 \mathrm{~cm}$ layer, due to the higher variability of OC stocks in subsoils.

\subsection{Relative contribution of error sources to $\mathrm{OC}$ stock variance}

Organic C stocks were calculated based on OC concentrations, bulk densities, and the fine earth fractions. Each of the variables contributed to the overall variability of OC stocks at the sites. For many sites, OC concentrations determined the variability of OC stocks within sites. Its relative importance grew with soil depth from $36 \pm 13 \%$ in the $0-5 \mathrm{~cm}$ layer to $73 \pm 19 \%$ at 50-60 cm soil depth (Fig. 5). Below $30 \mathrm{~cm}$ soil depth, OC concentrations were almost exclusively responsible for OC stock variances in the stone-poor soils at Hesse (75-86\%), Le Bray (77-87\%), Bugac (91-96\%), Gebesee (89-92\%) and Grignon (87-94\%). Across sites and land use types, the relative contribution of $\mathrm{BD}$ to the variance of $\mathrm{OC}$ stocks was largest for the uppermost soil layer $(28 \pm 17 \%)$ and declined with soil depth to only $4 \pm 3 \%$ in the $50-60 \mathrm{~cm}$ layer. The relative contribution expressed as fine earth content (FE) depended on the stone content with values ranging between $1-3 \%$ at the stone-poor site Hesse and 15-39\% at the more stony site at Carlow. At Norunda and Wetzstein, FE content was the dominant contributor to the variance of OC stocks and accounted for 26-49\% (Fig. 6). At most sites the fine earth proportion became more important for the variance of OC stocks than BD at a stone content larger than 10-20\%. 


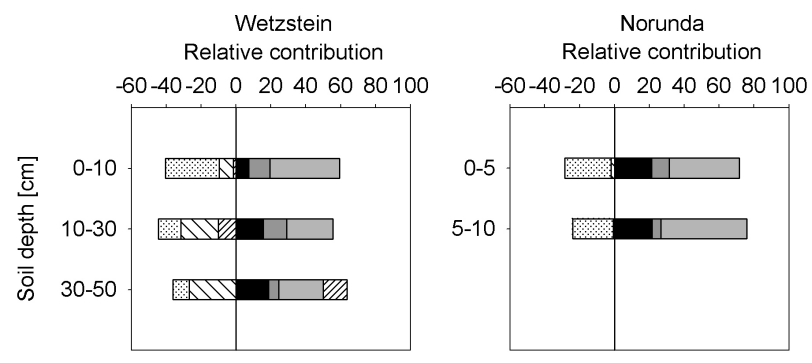

$\square$ OCc $\square$ BD $\square$ FE שm Covar OCc-BD $\square$ Covar OCc-FE

Fig. 6. Relative contribution of OC concentration (OCc), bulk density (BD), fine earth content (FE), and the covariances between OCc and $\mathrm{BD}, \mathrm{OCc}$ and $\mathrm{FE}$, and $\mathrm{BD}$ and $\mathrm{FE}$ to the variance of $\mathrm{OC}$ stocks at the stone rich coniferous forest sites Wetzstein and Norunda (soil depth in $\mathrm{cm}$, relative contribution in \%).

Part of the variance effects of OC concentrations and BD was counterbalanced by the negative covariance of both parameters (Fig. 4). On average across sites, the covariance contributed to $-25 \pm 14 \%$ in the $0-5 \mathrm{~cm}$ layer; this proportion decreased with soil depth to only $-10 \pm 7 \%$ at $50-$ $60 \mathrm{~cm}$. It was less important for the stone-rich sites Norunda and Wetzstein ( 0 and $-2 \%$ in the uppermost layer) than for the stone-poor forest sites.

The covariance between $\mathrm{BD}$ and FE contents was also negative as the high density of stones results in higher BD at places with low contributions of fine earth to total soil weight. It counterbalanced significant parts of the contributions of $\mathrm{BD}$ and $\mathrm{FE}$ contents to $\mathrm{OC}$ stock variances in the subsoil at Hainich $(-5$ to $-10 \%)$, Carlow $(-4$ to $-11 \%)$, Laqueuille $(-17$ to $-29 \%)$, Norunda $(-23$ to $-26 \%)$, and Wetzstein $(-9$ to $-31 \%)$. The covariance between OC concentrations and FE content was positive at some sites (e.g., Hainich with 16-20\% below $30 \mathrm{~cm}$ soil depth) and negative at others (e.g., at Carlow with -10 to $-31 \%$ ).

A comparison between the land use types reveals that the relative contribution of $\mathrm{BD}$ to $\mathrm{OC}$ stock variances was larger in the upper $30 \mathrm{~cm}$ of croplands than for deciduous forest sites (Fig. 6) while the negative covariance between OC concentration and BD tended to be less important for cropland sites. Results for grasslands were variable. The grassland site Laqueuille on volcanic parent material had a smaller contribution of $\mathrm{OC}$ concentrations and a larger one of BD to $\mathrm{OC}$ stock variance than the other two grassland sites.

\subsection{Minimum detectable difference of OC stocks}

Assuming paired re-sampling using 100 soil cores, the minimum detectable difference (MDD) can be statistically evaluated for each site (1-24 ha size) and soil depth. Absolute values for the MDD increased when larger soil volumes (e.g., $0-10 \mathrm{~cm}, 0-30 \mathrm{~cm}$ or $0-60 \mathrm{~cm}$ ) were considered $(\mathrm{Ta}-$ ble 2). When expressed relative to existing stocks, MDDs usually decreased when larger soil core segments were ana- lyzed within the upper $30 \mathrm{~cm}$ of the soil. In lower parts of the soil profile, between 30 and $60 \mathrm{~cm}$ depth, change detection relative to existing stocks is less feasible than in topsoil layers due to higher CV of OC stocks (Supplement Table A1).

A comparison of the different land use types reveals that croplands offer best opportunities to detect changes. Here changes as small as $78-133 \mathrm{~g} \mathrm{OC} \mathrm{m}^{-2}$ are detectable in the $0-10 \mathrm{~cm}$ layer $(3-7 \%$ of existing stocks) or $153-$ $276 \mathrm{~g} \mathrm{OC} \mathrm{m}^{-2}$ in $0-30 \mathrm{~cm}(2-5 \%)$. Respective values for $0-10 \mathrm{~cm}$ of the deciduous forests are $126-290 \mathrm{~g} \mathrm{OC} \mathrm{m}^{-2}(5-$ $8 \%$ ), and $143-270 \mathrm{~g} \mathrm{OC} \mathrm{m}^{-2}$ for the grasslands $(3-5 \%)$. Least chance to detect changes exists for the coniferous forests where MDD for 100 samples ranges between 269$288 \mathrm{~g} \mathrm{OC} \mathrm{m}^{-2}(9-16 \%)$. As only 80 soil pits were sampled at Norunda and 15 at Wetzstein, changes of $18-32 \%$ of existing stocks would be required in a paired resampling.

While small absolute changes seem detectable in the litter layers of the deciduous forests, changes relative to present stocks need to be higher than in the mineral soil (7$27 \%$ ). At the coniferous forest sites, changes as high as 454-764 $\mathrm{g} \mathrm{OC} \mathrm{m}^{-2}(10-20 \%)$ would be necessary to detect changes in the Oe-Oa horizon with 100 samples (Table 2).

\subsection{Organic C stock calculations based on equivalent soil masses}

Since a change in bulk densities between sampling times can affect the detection of differences in OC stocks when comparing fixed soil depths, OC stocks were also calculated for equivalent soil masses, as suggested by Ellert et al. (2002). Stocks calculated for pre-defined fine earth weights $(100$, $300,600 \mathrm{~kg} \mathrm{soil} \mathrm{m}^{-2}$ ) corresponded to different soil depths at individual sites. Material from soil surface down to 7 to $15 \mathrm{~cm}$ has to be considered to give $100 \mathrm{~kg} \mathrm{soil} \mathrm{m}^{-2}$, to 21 to $41 \mathrm{~cm}$ for $300 \mathrm{~kg} \mathrm{soil} \mathrm{m}^{-2}$, and to 40 to $>60 \mathrm{~cm}$ for $600 \mathrm{~kg}$ soil $\mathrm{m}^{-2}$. The main aim of our study was not comparing sites but to track temporal changes within sites. So, the mass limits were selected for each site individually, based on average soil masses per layer rather than using fixed equivalent weights across all sites.

Organic C stocks calculated for average soil masses per soil layer were similar to those for definite volumes (Table 2). Standard deviations and CVs of the upper layers at forest and grassland sites were often higher than those calculated for soil volumes (Table 2). Accordingly also the minimum detectable differences were generally slightly larger for the equivalent soil mass than for the fixed depth method (Fig. 7). In the upper $20 \mathrm{~cm}$ of the croplands on the other hand, variability of OC stocks calculated for soil masses was smaller than for fixed soil volumes and also the minimum detectable difference was less. 


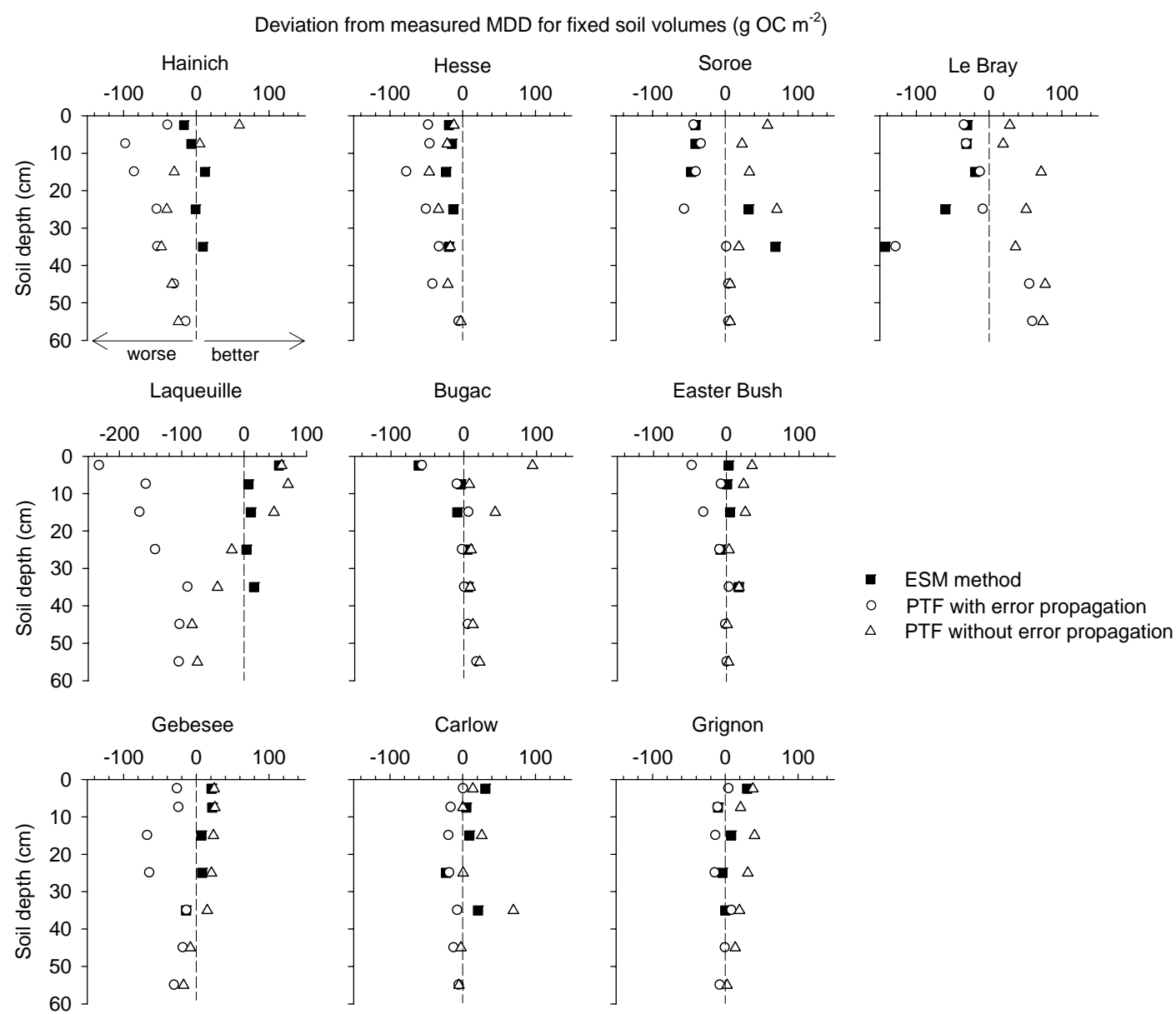

Fig. 7. Difference between minimum detectable difference (MDD) of measured OC stocks and (1) the MDD calculated for OC stocks expressed for equivalent soil masses (ESM) of respective layers, (2) the MDD of OC stocks calculated with BD estimated using a pedotransfer function (PTF) without error propagation, and (3) the MDD of OC stocks calculated with BD estimated by a PTF with error propagation at different sites.

\subsection{Organic C stock calculations using PTFs for estimation of BD}

The following results refer to the more general PTF including data from all sites. The application of a PTF for the estimation of BD without accounting for the associated error results in SOC stock variances that are smaller than the measured values, especially for topsoil layers. Also the minimum detectable difference (MDD) was smaller for those values than for measured ones (Fig. 7).

Including the uncertainty of BD estimates results in much larger variances. The application of error propagation raises the MDD on average by $70 \pm 43 \mathrm{~g} \mathrm{OC} \mathrm{m}^{-2}$ or by $50 \pm 20 \%$ in the uppermost soil layer, although differences were smaller in subsoil layers (excluding the volcanic site Laqueuille where differences were as high as $292 \mathrm{~g} \mathrm{OC} \mathrm{m}^{-2}$ ). When compared with measured values, MDDs based on PTF including error propagation were overall greater (Fig. 7). Average differences in MDD between measured and estimated
OC stocks were $32 \pm 22 \mathrm{~g} \mathrm{OC} \mathrm{m}^{-2}(29 \pm 22 \%$ of measured MDD), $30 \pm 28 \mathrm{~g} \mathrm{OC} \mathrm{m}^{-2}$ (34 $\left.\pm 29 \%\right)$, and $37 \pm 32 \mathrm{~g} \mathrm{OC} \mathrm{m}^{-2}$ $(32 \pm 36 \%)$ for the $0-5,5-10$ and $10-20 \mathrm{~cm}$ layers (excluding Laqueuille again).

The relative contribution of individual factors to the variance of SOC stocks was also affected by the application of the PTF (Fig. 5). The relative contribution of the uncertainty of BD to OC stock variances was on average 11-19\% higher for estimated (including error propagation) than for measured values in the upper $30 \mathrm{~cm}$ of the mineral soil. The relevance of OC concentrations was $8-12 \%$ smaller. Differences between measured and estimated values varied from site to site and with soil depth. Largest increases in the contribution of BD were observed for the grassland sites Laqueuille and Easter Bush, and the cropland sites Gebesee and Grignon. At these sites, BD became the dominant determinant of OC stock variances in the upper soil layers. The shift in the relative importance of BD for SOC stock variances was more pronounced in upper than in deeper soil layers. The 
negative covariance between $\mathrm{BD}$ and $\mathrm{FE}$ content in stonerich soils was ineffective when OC stocks were calculated with estimated values for BD. The negative covariance between $\mathrm{BD}$ and $\mathrm{OC}$ concentrations was often more important for OC stock variances based on estimated than measured $\mathrm{BD}$ values.

\section{Discussion}

\subsection{Soil OC stocks}

Organic $\mathrm{C}$ stocks at the 12 study sites are representative for CarboEurope main sites and in line with other studies on $\mathrm{C}$ stocks of similar temperate ecosystems as summarized in Jobbagy and Jackson (2000). One exception is the grassland site Laqueuille in the Massif Central, France, with large soil OC concentrations and stocks (22907 $\mathrm{g} \mathrm{m}^{-2}$, Table 2). This is because of the andic soils, wherein strong interactions between organic material and poorly-crystalline minerals (e.g., ferrihydrite and allophone) favor OC accumulation and stabilization (Shoji et al., 1993). Also, the coniferous forest soil at Le Bray had exceptionally large total OC stocks $\left(18135 \mathrm{~g} \mathrm{~m}^{-2}\right)$. These were mainly due to unusually high OC contents of deeper soil layers, which are caused by deep plowing prior to the establishment of the pine plantation, bringing organic forest floor layer material into deeper soil layers.

\subsection{Sources of uncertainty of soil OC stocks}

Greater importance of OC concentration than of BD variation for variability of OC stocks was also observed by Don et al. (2007) and Goidts et al. (2009a). The relative increase in contribution of OC concentrations to OC stock variations with soil depth can be the result of spatial variability e.g. caused by different lower boundaries of B horizons, or from larger relative measurement errors at deep soil layers due to OC concentrations close to the detection limit, and increasing carbonate contents.

Organic carbon concentration was not at all sites the most important determinant of OC stocks. There were some exceptions like the cropland sites where BD and fine earth content had a stronger impact on OC stock variability than OC concentrations in the upper soil layers. This is probably the result of mechanical soil disturbance by plowing. At the stone rich coniferous forest sites and the volcanic grassland site Laqueuille, fine earth content and BD were also more important than OC concentrations. The FE content contribution to $\mathrm{OC}$ stock variance increases with stone content and becomes dominant at high stone contents (approximately $>20 \%$ at our study sites). It should be noted that the correct determination of the stone content in stone-rich soils is notoriously difficult in the field (Stendahl et al., 2009) and adds to the natural variability of stones. Thus, soil cultivation, stone content, and parent material seem to modify the sources of uncertainty.

\subsection{Possibilities and limitations of the equivalent soil mass approach}

It is possible to reduce the influence of temporal changes in bulk densities by using the average amount of fine soil material $(<2 \mathrm{~mm})$ per area for calculation of OC stocks. Still, the method will always be limited by the impossibility to collect soil on mass basis so that it is necessary to take and analyze additional soil samples to ensure having enough material. The reduction or enlargement of sampled soil layers to achieve a predefined soil weight causes additional errors in calculated OC stocks (Gifford and Roderick, 2003; Ellert et al., 2001). Estimation of OC stocks based on definite soil masses accentuates differences in stocks between sites and soil cores as compared to the fixed soil depth method. This comes from the negative relation between OC concentration and $\mathrm{BD}$. To obtain a certain soil mass, a larger volume of soil of lower bulk density and thus higher OC concentration is required, while a smaller volume of samples is needed when soils have a larger BD and accordingly smaller OC concentration. This frequently results in higher CV and MDD for definite soil masses than for fixed soil volumes in surface soil layers (Table 2).

We did not determine $\mathrm{C}$ contents of stones. Therefore we determined OC stocks for fixed fine earth $(<2 \mathrm{~mm})$ masses. In this case, the mass or volume of stones is replaced by soil material from deeper layers to achieve a defined weight, while stones are equivalent to holes in the fixed volume approach. Using fixed soil weights reduces the relative variability of OC stocks as compared to definite volumes in soil layers with intermediate stone content (5-20\% stones), but it hampers the localization of OC stock changes within the soil profile. At sites with high stone contents, small scale spatial variability of fine earth masses was so high that the calculation of stocks based on average fine earth masses per layer was not reasonable. Not accounting for $\mathrm{C}$ stored in stones can result in site and stone type-related errors as OC contents of coarse soil fragments vary considerably (Corti et al., 2002; Harrison et al., 2003). Additional grinding and analyses of the coarse soil fragments would have greatly increased the analytical effort involved. It might be assumed that the fraction of $\mathrm{OC}$ in stones with fast turnover rate is small and does therefore not contribute significantly to total OC changes within the time periods considered. However, Agnelli et al. (2002) observed young OC in weathered sandstones of forest A horizons.

For the plowed soils at Carlow, Gebesee and Grignon, where relations between $\mathrm{OC}$ concentrations and bulk density are obscured by tillage, calculation of OC stocks for definite soil masses reduces variability and MDD (Table 2, Fig. 7). Bulk density of croplands is probably most dependent on the sampling time because of differences in type and timing of 
tillage as well as in crop rotation. Therefore, calculation of OC stocks based on equivalent soil masses is especially recommended for detection of changes at cropland sites. Also, for the other land use types bulk density can vary with time or season, e.g., because of changes in OC concentrations or water contents (Hopkins et al., 2009). As ignoring changes in BD with time can lead to wrong estimates of soil OC changes, calculation of OC stocks based on equivalent soil masses is generally recommended for the determination of SOC stock changes in soils with low to intermediate stone contents.

\subsection{Applicability of PTF for the detection of changes in soil OC}

The pedotransfer function (PTF) applied here was directly derived from the study sites. We did not include soil texture as data were not available for all samples and because De Vos et al. (2005) concluded that the addition of soil texture only slightly improves the predictive power of PTFs. Higher bulk densities usually occur at deeper soil layers due to the weight of overlying soil. The influence of soil depth on bulk density estimation via PTF is considered to be small (Heuscher et al., 2005; De Vos et al., 2005), warranting the inclusion of soil samples from all soil layers in the applied PTF. While a number of equations were used to describe the relation between BD and OC concentrations in PTFs (De Vos et al., 2005), an exponential function fitted our data best, similar as observed by Ruehlmann and Körschens (2009). Thus, it can be assumed that the PTF applied to estimate BD was reasonable and can be used to test consequences for the detection of OC changes. As we assume the stone content to be known (which is usually not the case when PTFs are applied) and the PTF was produced for the study sites, our results present an optimistic scenario for the application of PTFs for BD estimation.

The use of PTFs for estimation of BD can lead to wrong or biased OC stocks. The average deviation from measured OC stocks was frequently larger than the MDD at our study sites (Supplement Table A2). As it would need a repeated dataset to quantify the effect of the methodological bias on differences between stocks at two sampling dates, we will not discuss this issue further here and only highlight its possible impact.

The estimation of BD using PTF also influences the variance of OC stocks and thus the possibility to achieve significant results. Our results show that by not accounting for the additional uncertainty introduced to stock estimates by the PTF leads to significant underestimation of the total variance at the plot/field scale. Measurement of BD gives better possibility to detect OC stock changes than estimation via PTF only if the error associated with the application of the PTF is accounted for. As most of the studies summarized in Table 1 estimated BD without accounting for the additional error of the PTF, some results might not have been significant when considering all uncertainties.

The necessity to account for changes in BD with time in order to achieve accurate results is discussed above. Similar corrections for changes in soil mass per area cannot be done by estimating BD via the presented PTF. These functions can account for changes in BD with time only when changes are caused by shifts in OC concentrations. When considering a pre-set soil depth, for example $0-15 \mathrm{~cm}$, the PTF-based results will underestimate gains in OC stocks in case $\mathrm{C}$ concentrations increase with time (and BDs decrease accordingly), and underestimate losses when $\mathrm{C}$ concentrations decrease. Direct measurement of BD at the time of sampling might be laborious but improves change detectability and leads to more accurate results.

\subsection{How long will it take until changes become detectable with 100 samples?}

In order to estimate the time period necessary to pass before a change in soil OC stocks can be detected, we used trends and standard deviations given in Schulze et al. (2009). For forests, the average assumed gain of $20 \pm 12 \mathrm{gC} \mathrm{m}^{-2} \mathrm{yr}^{-1}$ would lead to detectable differences after 7 (4-19) yr at Hesse, 11 (7-31) yr at Hainich, and 15 (9-41) yr at Sorø, assuming all changes to occur within the upper $10 \mathrm{~cm}$ of the mineral soil (Fig. 8). Detection of changes requires longer times when changes are distributed over a larger soil volume, while it can be slightly faster if restricted to certain layers in the subsoil, due to differences in MDD (Fig. 8, Table 2). The repeated inventories summarized in Table 1 indicate that changes of $20-30 \mathrm{gC} \mathrm{m}^{-2} \mathrm{yr}^{-1}$ could be a realistic assumption for European forest soils, though local changes might be larger. Trends based on flux measurements at the study sites indicate almost no change at Hainich and losses of 20 to $30 \mathrm{~g} \mathrm{~m}^{-2} \mathrm{yr}^{-1}$ at Hesse (Table 3).

Change detection is more difficult for the coniferous forest sites because of the higher spatial variability. Assuming 100 samples, changes of $20 \mathrm{gC} \mathrm{m}^{-2} \mathrm{yr}^{-1}$ would only be detectable after $25-40 \mathrm{yr}$ in the organic layers or after $15 \mathrm{yr}$ in the upper $10 \mathrm{~cm}$ of the mineral soil. With the smaller number of samples taken during the first sampling, it would take $30 \mathrm{yr}$ at Norunda ( 80 samples) and more than $100 \mathrm{yr}$ to detect changes in the litter layer at the Wetzstein site (15 samples). In the upper mineral soil $(0.10 \mathrm{~cm})$, changes would be detectable after 15 and $36 \mathrm{yr}$, respectively. Different from the stone-free sites where soil corer can be applied, soil pits need to be analyzed in stone rich soils which is much more laborious and destructive to the site both impeding very large sample numbers. It seems the detection of changes in organic layers of coniferous forests can be more difficult than in the mineral soil and that stony sites might not be suitable for change detection at decadal time scales unless it is possible to use very high sample numbers. 

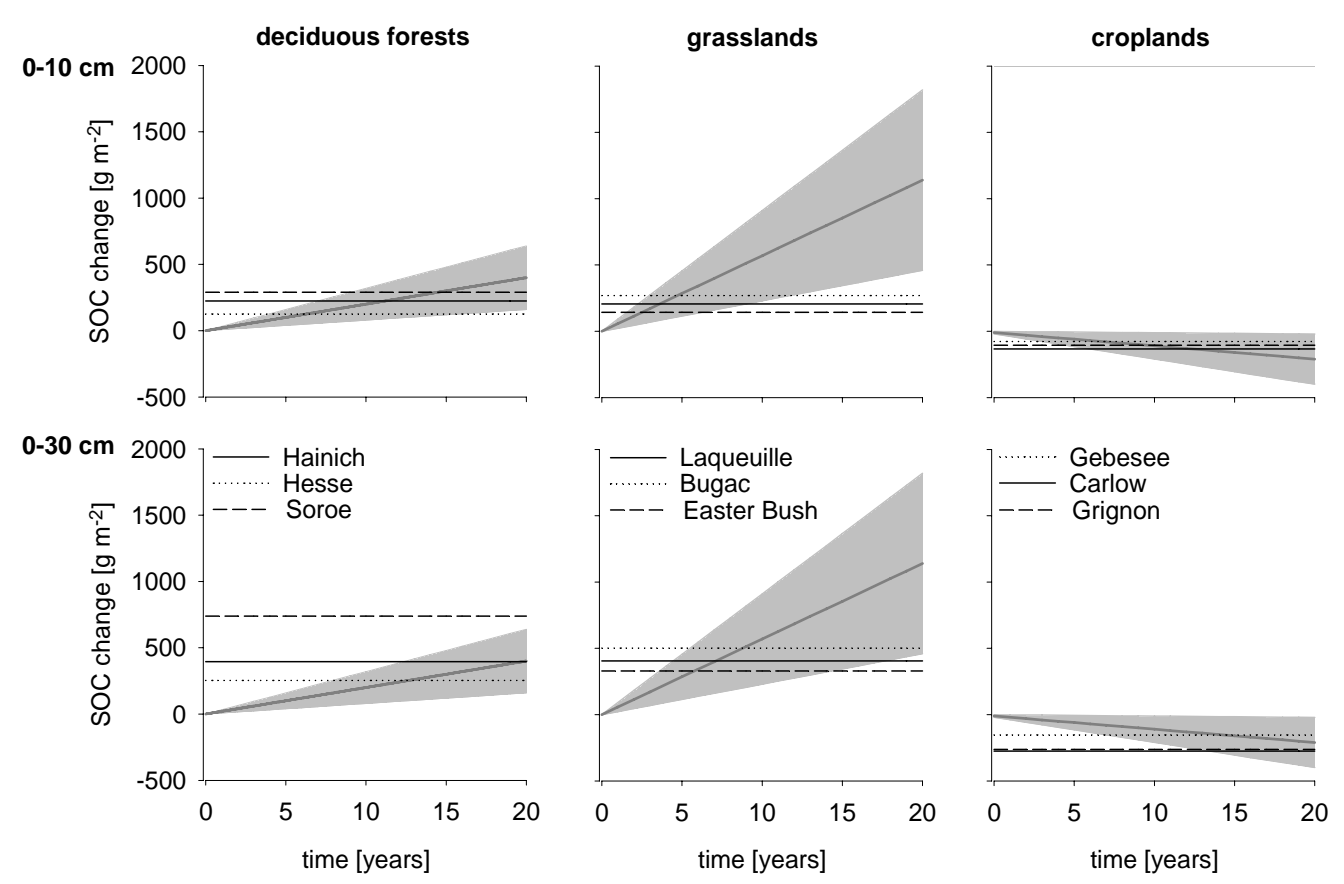

Fig. 8. Estimated linear changes in SOC with time based on values presented in Schulze et al. (2009) for different land use types ( \pm standard deviation as grey shade). Horizontal lines present the minimum detectable difference of SOC stocks at individual sites for $0-10$ and $0-30 \mathrm{~cm}$ soil depth. The intersections between the curves indicate the time necessary to detect a change at the sites.

Table 3. Expected changes in soil organic carbon stocks based on flux measurements. Calculation of changes in SOC was performed as follows: Forests: ${ }^{\mathrm{a}} \Delta \mathrm{SOC}=$ litter input - heterotrophic respiration; ${ }^{\mathrm{b}} \Delta \mathrm{SOC}=\mathrm{NEE}-\Delta$ biomass Grasslands: $\Delta \mathrm{SOC}=\mathrm{NEE}-$ harvest/grazing + fertilizer $\mathrm{C}$ input; Croplands: $\Delta \mathrm{SOC}=\mathrm{NEE}-$ harvest + fertilizer $\mathrm{C}$ input.

\begin{tabular}{|c|c|c|c|c|c|c|}
\hline & Years & $\begin{array}{r}\text { Average } \Delta \mathrm{SOC} \\
\text { per year } \\
\mathrm{gC} \mathrm{m}^{-2}\end{array}$ & $\begin{array}{r}\text { Annual min } \\
\mathrm{gC} \mathrm{m}^{-2}\end{array}$ & $\begin{array}{l}\text { Annual max } \\
\mathrm{gC} \mathrm{m}^{-2}\end{array}$ & $\begin{array}{r}\text { Average } \Delta \text { SOC } \\
\text { after } 5 / 10 \mathrm{yr} \\
\mathrm{gC} \mathrm{m}^{-2}\end{array}$ & $\begin{array}{r}\mathrm{MDD} \\
0-10 \mathrm{~cm} ; 0-30 \mathrm{~cm} \\
\mathrm{gC} \mathrm{m}^{-2}\end{array}$ \\
\hline \multicolumn{7}{|l|}{ Forests } \\
\hline Hainich $^{1}$ & $2000-2007$ & $\begin{array}{r}1^{\mathrm{a}} \\
\left(35^{*}\right)\end{array}$ & $\begin{array}{r}-46 \\
\left(-11^{*}\right)\end{array}$ & $\begin{array}{r}42 \\
\left(788^{*}\right)\end{array}$ & $\begin{array}{c}5\left(175^{*}\right) / \\
10\left(350^{*}\right)\end{array}$ & $224 ; 395$ \\
\hline Hesse $^{2}$ & 1996-2005 & $\begin{array}{l}-33^{\mathrm{b}} \\
-24^{\mathrm{a}}\end{array}$ & $\begin{array}{r}-258 \\
-99\end{array}$ & $\begin{array}{r}169 \\
44\end{array}$ & $\begin{array}{l}-163 /-325 \\
-120 /-240\end{array}$ & $126 ; 253$ \\
\hline Grasslands $^{3}$ & & $104 \pm 73$ & & & $520 / 1040$ & \\
\hline Laqueuille $^{3}$ & $2002-2004$ & 65 & 44 & 86 & $325 / 650$ & $205 ; 407$ \\
\hline Bugac $^{3,4,5}$ & $\begin{array}{l}2002-2004 \\
2003-2004 \\
2003\end{array}$ & 68 & $\begin{array}{r}12 \\
-80 \\
-96\end{array}$ & $\begin{array}{l}124 \\
188\end{array}$ & $340 / 680$ & $\begin{array}{l}270 ; 503 \\
270 ; 503\end{array}$ \\
\hline Easter Bush ${ }^{3}$ & $2002-2004$ & 231 & 161 & 300 & $1153 / 2310$ & $143 ; 329$ \\
\hline Croplands $^{6}$ & & $-95 \pm 87$ & & & $-475 /-950$ & \\
\hline Gebesee $^{6}$ & 2004-2007 & -56 & & & $-280 /-560$ & $78 ; 153$ \\
\hline Carlow $^{6}$ & 2004-2007 & -78 & & & $-390 /-780$ & $133 ; 276$ \\
\hline Grignon $^{7}$ & 2005-2009 & -130 & & & $-650 /-1300$ & $105 ; 263$ \\
\hline
\end{tabular}

${ }^{1}$ Kutsch et al. (2010b); ${ }^{2}$ Granier et al. (2008); ${ }^{3}$ Soussana et al. (2007); ${ }^{4}$ Nagy et al. (2007); ${ }^{5}$ Gilmanov et al. (2007); ${ }^{6}$ Kutsch et al. (2010a); ${ }^{7}$ Loubet et al. (2011).

* Based on soil respiration from laboratory incubation studies. 
For the grassland sites, a high soil OC accumulation rate of $57 \pm 34 \mathrm{~g} \mathrm{~m}^{-2} \mathrm{yr}^{-1}$ was calculated by Schulze et al. (2009). This change could be detected after 2 (2-6) yr at Easter Bush, 4 (2-9) yr at Laqueuille, and 5 (3-12) yr at Bugac in the upper $10 \mathrm{~cm}$ of the mineral soil. Other studies indicate similar or even larger gains of soil OC for European grasslands: Soussana et al. (2007) reported 104 \pm 73 ; Janssens et al. (2005) 60; Vleeshouwers and Verhagen (2002) $52 \mathrm{~g} \mathrm{OC} \mathrm{m}^{-2} \mathrm{yr}^{-1}$. Such OC changes are not confirmed by repeated inventories, which are mainly from Belgium and indicate SOC losses for the last decade, with few longer term studies observing gains (Table 1).

Croplands were the only land use assumed to lose soils $\mathrm{OC}$ at a rate of $10 \pm 9 \mathrm{~g} \mathrm{~m}^{-2} \mathrm{yr}^{-1}$ Schulze et al. (2009). Due to the small rate, it would take 8 (4-80)yr at Gebesee, $11(6-110)$ yr at Grignon, and $13(7-130)$ yr at Carlow to detect a significant change at $0-10 \mathrm{~cm}$ soil depth, despite the smaller spatial variability at the croplands than at other sites. Net biome productivity (NBP) estimates based on four year averages of eddy covariance measurements on seven European cropland sites indicate much larger OC losses of $95 \pm 87 \mathrm{~g} \mathrm{~m}^{-2} \mathrm{yr}^{-1}$ (Kutsch et al., 2010a). For the sites Gebesee and Carlow, NBP of 56 and $78 \mathrm{gC} \mathrm{m}^{-2} \mathrm{yr}^{-1}$ were calculated based on flux measurements. Such changes, if occurring in the upper $10 \mathrm{~cm}$ of the mineral soil, would be detectable after $2 \mathrm{yr}$ by a repeated inventory, or after 3-4 yr if being distributed over the plow layer $(0-30 \mathrm{~cm})$. Most of the results obtained by regional repeated inventories of croplands also detected soil OC losses $>10 \mathrm{~g} \mathrm{~m}^{-2} \mathrm{yr}^{-1}$ (Table 1), indicating that changes might become detectable sooner than assumed in Fig. 8. Usage of different repeated inventories for determination of average rates of change across Europe could be biased towards published results mainly focusing on sites with significant changes but setting aside sites with insignificant changes.

\subsection{Long-term trends and interannual variability}

Some long-term soil studies indicate trends in soil OC stocks being neither linear nor consistent. Johnson et al. (2007) showed increasing soil OC concentrations from 1972-1982 in a forested watershed in Tennessee, followed by a decrease towards 1993, but an increase again by 2004. In Belgium, largest soil OC stocks of grasslands were observed in 1990, while those of 1960 and 2000 were smaller (Lettens et al., 2005a). These results indicate that fluctuations in trends in soil OC, e.g., because of management changes, could occur at shorter time periods than those necessary to allow for detection of stock changes by repeated sampling. Besides longer term trends, there will also be some annual variability e.g. caused by year-to-year variations in temperature or rainfall. As it is assumed that annual changes in soil OC are too small to be detectable by a repeated soil inventory, flux measurements are used (Rodeghiero et al., 2010a). Some results are summarized in Table 3 and show that the interannual vari- ability of fluxes is considerable and exceeds long-term averages by far. Davis et al. (2010) concluded that the high spatial and temporal variability of flux-based net biome productivity (NBP) estimates at cropland sites hampers the application of annual NBP to predict trends in soil C stocks. And after all, ecosystem flux measurements have large uncertainties, too. We have to be aware that in case of large year-to-year variations in soil OC fluxes the selection of years for repeated sampling will influence results. At cropland and some grassland sites it is also important to take into account the time of the last application of organic fertilizers. It will not be possible to distinguish between interannual variability and long-term trends by a single re-sampling. Therefore it seems advisable to run repeated soil inventories along time series instead of just doing one re-sampling after a long period of time.

\section{Summary and conclusion}

The large uncertainties of current estimates of soil OC changes in Europe suggest that more repeated inventories are needed to complement model and flux studies. Our results show that repeated soil sampling of 100 soil cores at the field scale can be enough to determine SOC changes within $10 \mathrm{yr}$ time. Considering soil parameters only, best chance to detect changes exists for the croplands, least for the coniferous forest and stone-rich sites. Overall, detection is easier when changes are restricted to certain soil layers rather than being evenly distributed throughout the soil profile. Contribution of OC concentration, bulk densities or fine earth fraction to the variance of OC stocks varied with soil depth. While OC concentration was the most important determinant of OC stock variance in undisturbed forest and grassland sites with low stone contents, bulk densities or fine earth fraction became more important in topsoil layers of croplands and in stone-rich soils. Although it increased the uncertainty of OC stocks of most undisturbed soils, we recommend the expression of OC stocks in equivalent soil masses rather than fixed soil depths to account for temporal changes in bulk density, especially at the cropland sites. The estimation of bulk density by pedotransfer functions (PTF) seriously underestimates OC stock variances and thus overestimates the ability to detect changes if the error associated with the function is not accounted for. Changes claimed by past soil OC inventories where bulk density was not measured but derived from PTF, need to be re-considered carefully since most of them did not account for the uncertainty added to stock estimates by the function. The application of PTF to derive bulk densities is not recommended for future monitoring projects as changes are easier detectable with measured values and no reasonable procedure is available to allow for accounting of changes in BD with time. Instead we recommend continuous soil monitoring at time intervals of $10 \mathrm{yr}$ (to compromise between detectability of changes and temporal shifts in trends), 
the measurement of all relevant soil parameters to a sufficient soil depth (including subsoils), and expression of results in equivalent soil masses.

\section{Supplementary material related to this article is available online at: http://www.biogeosciences.net/8/1193/2011/ bg-8-1193-2011-supplement.pdf.}

Acknowledgements. The study was funded by the European Union. We are grateful to Marco Pöhlmann for assistance during sampling and soil analyses. We are indebted to numerous students for their help with fieldwork and sample preparation. For doing uncountable $\mathrm{C}$ and $\mathrm{N}$ analyses, we would like to thank the Routine Measurements and Analyses (Roma) Department, Max-Planck Institute for Biogeochemistry, especially Ines Hilke and Birgit Fröhlich, and Gerlinde Hardt and Christine Krenkewitz at the Soil Science Department, Martin Luther University Halle-Wittenberg. We thank Susan Trumbore for helpful discussions and comments on an earlier version of the manuscript. Finally, we thank all site managers for their support during sampling and with site-related questions.

The service charges for this open access publication have been covered by the Max Planck Society.

Edited by: J. Leifeld

\section{References}

Agnelli, A., Trumbore, S. E., Corti, G., and Ugolini, F. C.: The dynamics of organic matter in rock fragments in soil investigated by ${ }^{14} \mathrm{C}$ dating and measurements of ${ }^{13} \mathrm{C}$, Eur. J. Soil Sci., 53, 147-159, 2002.

Bellamy, P. H., Loveland, P. J., Bradley, R. I., Lark, R. M., and Kirk, G. J. D.: Carbon losses from all soils across England and Wales 1978-2003, Nature, 437, 245-248, 2005.

Berg, B., Johansson, M. B., Nilsson, A., Gundersen, P., and Norell, L.: Sequestration of carbon in the humus layer of Swedish forests - direct measurements, Can. J. Forest Res., 39, 962-975, 2009.

Conant, R. T. and Paustian, K.: Spatial variability of soil organic carbon in grasslands: implications for detecting change at different scales, Environ. Pollut., 116, S127-S135, 2002.

Conen, F., Zerva, A., Arrouays, D., Jolivet, C., Jarvis, P. G., Grace, J., and Mencuccini, M.: The carbon balance of forest soils: detectability of changes in soil carbon stocks in temperate and Boreal forests, SEB Exp. Biol. Ser., 235-249, 2005.

Corti, G., Ugolini, F. C., Agnelli, A., Certini, G., Cuniglio, R., Berna, F., and Sanjurjo, M. J. F.: The soil skeleton, a forgotten pool of carbon and nitrogen in soil, Eur. J. Soil Sci., 53, 283-298, 2002.

Davis, P. A., Brown, J. C., Saunders, M., Lanigan, G., Wright, E., Fortune, T., Burke, J., Connolly, J., Jones, M. B., and Osborne, B.: Assessing the effects of agricultural management practices on carbon fluxes: Spatial variation and the need for replicated estimates of Net Ecosystem Exchange, Agr. Forest Meteorol., 150, 564-574, 2010.
De Vos, B., Van Meirvenne, M., Quataert, P., Deckers, J., and Muys, B.: Predictive quality of pedotransfer functions for estimating bulk density of forest soils, Soil Sci. Soc. Am. J., 69, 500-510, 2005.

Dersch, G. and Böhm, K.: Anteil der Landwirtschaft an der Emission klimarelevanter Spurengase in Österreich, Die Bodenkultur, 48, 115-129, 1997.

Don, A., Schumacher, J., Scherer-Lorenzen, M., Scholten, T., and Schulze, E. D.: Spatial and vertical variation of soil carbon at two grassland sites - Implications for measuring soil carbon stocks, Geoderma, 141, 272-282, 2007.

Ellert, B. H. and Bettany, J. R.: Calculation of organic matter and nutrients stored in soils under contrasting management regimes, Can. J. Soil Sci., 75, 529-538, 1995.

Ellert, B. H., Janzen, H. H., and McConkey, B. G.: Measuring and comparing soil carbon storage, in: Assessment methods for soil carbon, edited by: Lal, R., Kimble, J. M., Follett, R. F., and Stewart, B. A., CRC Press LLC, Boca Raton, 131-146, 2001.

Ellert, B. H., Janzen, H. H., and Entz, T.: Assessment of a method to measure temporal change in soil carbon storage, Soil Sci. Soc. Am. J., 66, 1687-1695, 2002.

Fahey, T. J., Siccama, T. G., Driscoll, C. T., Likens, G. E., Campbell, J., Johnson, C. E., Battles, J. J., Aber, J. D., Cole, J. J., Fisk, M. C., Groffman, P. M., Hamburg, S. P., Holmes, R. T., Schwarz, P. A., and Yanai, R. D.: The biogeochemistry of carbon at Hubbard Brook, Biogeochemistry, 75, 109-176, 2005.

Garten, C. T. and Wullschleger, S. D.: Soil carbon inventories under a bioenergy crop (switchgrass): Measurement limitations, J. Environ. Qual., 28, 1359-1365, 1999.

Gifford, R. M. and Roderick, M. L.: Soil carbon stocks and bulk density: spatial or cumulative mass coordinates as a basis of expression?, Glob. Change Biol., 9, 1507-1514, 2003.

Gilmanov, T. G., Soussana, J. E., Aires, L., Allard, V., Ammann, C., Balzarolo, M., Barcza, Z., Bernhofer, C., Campbell, C. L., Cernusca, A., Cescatti, A., Clifton-Brown, J., Dirks, B. O. M., Dore, S., Eugster, W., Fuhrer, J., Gimeno, C., Gruenwald, T., Haszpra, L., Hensen, A., Ibrom, A., Jacobs, A. F. G., Jones, M. B., Lanigan, G., Laurila, T., Lohila, A., Manca, G., Marcolla, B., Nagy, Z., Pilegaard, K., Pinter, K., Pio, C., Raschi, A., Rogiers, N., Sanz, M. J., Stefani, P., Sutton, M., Tuba, Z., Valentini, R., Williams, M. L., and Wohlfahrt, G.: Partitioning European grassland net ecosystem $\mathrm{CO}_{2}$ exchange into gross primary productivity and ecosystem respiration using light response function analysis, Agr. Ecosyst. Environ., 121, 93-120, 2007.

Goidts, E. and van Wesemael, B.: Regional assessment of soil organic carbon changes under agriculture in Southern Belgium (1955-2005), Geoderma, 141, 341-354, 2007.

Goidts, E., van Wesemael, B., and Crucifix, M.: Magnitude and sources of uncertainties in soil organic carbon (SOC) stock assessments at various scales, Eur. J. Soil Sci., 60, 723-739, 2009a.

Goidts, E., van Wesemael, B., and Van Oost, K.: Driving forces of soil organic carbon evolution at the landscape and regional scale using data from a stratified soil monitoring, Glob. Change Biol., 15, 2981-3000, 2009b.

Granier, A., Breda, N., Longdoz, B., Gross, P., and Ngao, J.: Ten years of fluxes and stand growth in a young beech forest at Hesse, North-eastern France, Ann. For. Sci., 65, 1-13, 2008.

Hanegraaf, M. C., Hoffland, E., Kuikman, P. J., and Brussaard, L.: Trends in soil organic matter contents in Dutch grasslands and 
maize fields on sandy soils, Eur. J. Soil Sci., 60, 213-222, 2009.

Harrison, R. B., Adams, A. B., Licata, C., Flaming, B., Wagoner, G. L., Carpenter, P., and Vance, E. D.: Quantifying deep-soil and coarse-soil fractions: Avoiding sampling bias, Soil Sci. Soc. Am. J., 67, 1602-1606, 2003.

Heidmann, T., Christensen, B. T., and Olesen, S. E.: Changes in soil $\mathrm{C}$ and $\mathrm{N}$ content in different cropping systems and soil types, Greenhouse Gas Inventories for Agriculture in the Nordic Countries, Ministry of Food, Agriculture and Fisheries, Danish Institute of Agricultural Sciences, Helsingør, 77-86, 2002.

Heuscher, S. A., Brandt, C. C., and Jardine, P. M.: Using soil physical and chemical properties to estimate bulk density, Soil Sci. Soc. Am. J., 69, 51-56, 2005.

Hintze, J.: NSCC and PASS, Number Cruncher Statistical Systems, Kaysville, Utah, 2001.

Hopkins, D. W., Waite, I. S., McNicol, J. W., Poulton, P. R., Macdonald, A. J., and O'Donnell, A. G.: Soil organic carbon contents in long-term experimental grassland plots in the UK (Palace Leas and Park Grass) have not changed consistently in recent decades, Glob. Change Biol., 15, 1739-1754, 2009.

Janssens, I. A., Freibauer, A., Schlamadinger, B., Ceulemans, R., Ciais, P., Dolman, A. J., Heimann, M., Nabuurs, G.-J., Smith, P., Valentini, R., and Schulze, E.-D.: The carbon budget of terrestrial ecosystems at country-scale - a European case study, Biogeosciences, 2, 15-26, doi:10.5194/bg-2-15-2005, 2005.

Janssens, I. A., Dieleman, W., Luyssaert, S., Subke, J. A., Reichstein, M., Ceulemans, R., Ciais, P., Dolman, A. J., Grace, J., Matteucci, G., Papale, D., Piao, S. L., Schulze, E. D., Tang, J., and Law, B. E.: Reduction of forest soil respiration in response to nitrogen deposition, Nat. Geosci., 3, 315-322, 2010.

Jobbagy, E. G. and Jackson, R. B.: The vertical distribution of soil organic carbon and its relation to climate and vegetation, Ecol. Appl., 10, 423-436, 2000.

Johnson, D. W., Todd, D. E., Trettin, C. F., and Sedinger, J. S.: Soil carbon and nitrogen changes in forests of walker branch watershed, 1972 to 2004, Soil Sci. Soc. Am. J., 71, 1639-1646, 2007.

Kiser, L. C., Kelly, J. M., and Mays, P. A.: Changes in Forest Soil Carbon and Nitrogen after a Thirty-Year Interval, Soil Sci. Soc. Am. J., 73, 647-653, 2009.

Kutsch, W. L., Aubinet, M., Buchmann, N., Smith, P., Osborne, B., Eugster, W., Wattenbach, M., Schrumpf, M., Schulze, E. D., Tomelleri, E., Ceschia, E., Bernhofer, C., Béziat, P., Carrara, A., Di Tommasi, P., Grünwald, T., Jones, M., Magliulo, V., Marloie, O., Moureaux, C., Olioso, A., Sanz, M. J., Saunders, M., Søgaard, H., and Ziegler, W.: The net biome production of full crop rotations in Europe, Agr. Ecosyst. Environ., 139, 336-345, doi:10.1016/j.agee.2010.07.016, 2010a.

Kutsch, W. L., Persson, T., Schrumpf, M., Moyano, F. E., Mund, M., Andersson, S., and Schulze, E. D.: Heterotrophic soil respiration and soil carbon dynamics in the deciduous Hainich forest obtained by three approaches, Biogeochemistry, 100, 167-183, doi:10.1007/s10533-010-9414-9, 2010b.

Lee, J., Hopmans, J. W., Rolston, D. E., Baer, S. G., and Six, J.: Determining soil carbon stock changes: Simple bulk density corrections fail, Agr. Ecosyst. Environ., 134, 251-256, 2009.

Lettens, S., van Orshoven, J., van Wesemael, B., Muys, B., and Perrin, D.: Soil organic carbon changes in landscape units of Belgium between 1960 and 2000 with reference to 1990, Glob. Change Biol., 11, 2128-2140, 2005 a.
Lettens, S., Van Orshovena, J., van Wesemael, B., De Vos, B., and Muys, B.: Stocks and fluxes of soil organic carbon for landscape units in Belgium derived from heterogeneous data sets for 1990 and 2000, Geoderma, 127, 11-23, 2005b.

Loubet, B., Laville, P., Lehuger, S., Larmanou, E., Flechard, C., Mascher, N., Genermont, S., Roche, R., Ferrara, R. M., Stella, P., Personne, E., Durand, B., Decuq, C., Fura, D., Masson, S., Fanucci, O., Rampon, J.-N., Siemens, J., Kindler, R., Gabrielle, B., Schrumpf, M., and Cellier, P.: Measurement base carbon, nitrogen and GHG balances of a four years crop rotation, Plant Soil, doi:10.1007/s11104-011-0751-9, in press, 2011.

Mäkelä-Kurtto, R. and Sippola, J.: Monitoring of Finnish arable land: changes in soil quality between 1987 and 1998, Agr. Food Sci. Finland, 11, 273-284, 2002.

Meersmans, J., Van Wesemael, B., De Ridder, F., Dotti, M. F., De Baets, S., and Van Molle, M.: Changes in organic carbon distribution with depth in agricultural soils in northern Belgium, 1960-2006, Glob. Change Biol., 15, 2739-2750, 2009.

Mestdagh, I., Sleutel, S., Lootens, P., Van Cleemput, O., Beheydt, D., Boeckx, P., De Neve, S., Hofman, G., Van Camp, N., Vande Walle, I., Samson, R., Verheyen, K., Lemeur, R., and Carlier, L.: Soil organic carbon-stock changes in Flemish grassland soils from 1990 to 2000, J. Plant Nutr. Soil Sc., 172, 24-31, 2009.

Nagy, Z., Pinter, K., Czobel, S., Balogh, J., Horvath, L., Foti, S., Barcza, Z., Weidinger, T., Csintalan, Z., Dinh, N. Q., Grosz, B., and Tuba, Z.: The carbon budget of semi-arid grassland in a wet and a dry year in Hungary, Agr. Ecosyst. Environ., 121, 21-29, 2007.

Palmer, C. J., Smith, W. D., and Conkling, B. L.: Development of a protocol for monitoring status and trends in forest soil carbon at a national level, Environ. Pollut., 116, S209-S219, 2002.

Reijneveld, A., van Wensem, J., and Oenema, O.: Soil organic carbon contents of agricultural land in the Netherlands between 1984 and 2004, Geoderma, 152, 231-238, 2009.

Riley, H. and Bakkegard, M.: Declines of soil organic matter content under arable cropping in southeast Norway, Acta Agr. Scand. B-S. P., 56, 217-223, 2006.

Rodeghiero, M., Heinemeyer, A., Schrumpf, M., and Bellamy, P. H.: Determination of changes in soil organic carbon stocks, in: Integrated Methodology on soil carbon flux measurements, edited by: Kutsch, W., Bahn, M., and Heinemeyer, A., Cambridge University Press, Cambridge, 2010a.

Rodeghiero, M., Tonolli, S., Vescovo, L., Gianelle, D., Cescatti, A., and Sottocornola, M.: INFOCARB: A regional scale forest carbon inventory (Provincia Autonoma di Trento, Southern Italian Alps), Forest Ecol. Manag., 259, 1093-1101, 2010b.

Ruehlmann, J. and Körschens, M.: Calculating the Effect of Soil Organic Matter Concentration on Soil Bulk Density, Soil Sci. Soc. Am. J., 73, 876-885, 2009.

Saby, N. P. A., Arrouays, D., Antoni, V., Lemercier, B., Follain, S., Walter, C., and Schvartz, C.: Changes in soil organic carbon in a mountainous French region, 1990-2004, Soil Use Manage., 24, 254-262, 2008a.

Saby, N. P. A., Bellamy, P. H., Morvan, X., Arrouays, D., Jones, R. J. A., Verheijen, F. G. A., Kibblewhite, M. G., Verdoodt, A., Berenyiuveges, J., Freudenschuss, A., and Simota, C.: Will European soil-monitoring networks be able to detect changes in topsoil organic carbon content?, Glob. Change Biol., 14, 24322442, 2008b. 
Schimel, D. S.: Terrestrial Ecosystems and the Carbon-Cycle, Glob. Change Biol., 1, 77-91, 1995.

Schulze, E. D., Luyssaert, S., Ciais, P., Freibauer, A., Janssens, I. A., Soussana, J. F., Smith, P., Grace, J., Levin, I., Thiruchittampalam, B., Heimann, M., Dolman, A. J., Valentini, R., Bousquet, P., Peylin, P., Peters, W., Rodenbeck, C., Etiope, G., Vuichard, N., Wattenbach, M., Nabuurs, G. J., Poussi, Z., Nieschulze, J., and Gash, J. H.: Importance of methane and nitrous oxide for Europe's terrestrial greenhouse-gas balance, Nat. Geosci., 2, 842$850,2009$.

Shoji, S., Nanzyo, M., and Dahlgren, R. A.: Volcanic ash soils, Elsevier, Amsterdam, 288 pp., 1993.

Sleutel, S., De Neve, S., Hofman, G., Boeckx, P., Beheydt, D., Van Cleemput, O., Mestdagh, I., Lootens, P., Carlier, L., Van Camp, N., Verbeeck, H., Vande Walle, I., Samson, R., Lust, N., and Lemeur, R.: Carbon stock changes and carbon sequestration potential of Flemish cropland soils, Glob. Change Biol., 9, 11931203, 2003.

Sleutel, S., De Neve, S., Singier, B., and Hofman, G.: Organic C levels in intensively managed arable soils - long-term regional trends and characterization of fractions, Soil Use Manage., 22, 188-196, 2006.

Smith, P.: How long before a change in soil organic carbon can be detected?, Glob. Change Biol., 10, 1878-1883, 2004.

Smith, P., Chapman, S. J., Scott, W. A., Black, H. I. J., Wattenbach, M., Milne, R., Campbell, C. D., Lilly, A., Ostle, N., Levy, P. E., Lumsdon, D. G., Millard, P., Towers, W., Zaehle, S., and Smith, J. U.: Climate change cannot be entirely responsible for soil carbon loss observed in England and Wales, 1978-2003, Glob. Change Biol., 13, 2605-2609, 2007.

Soussana, J. F., Allard, V., Pilegaard, K., Ambus, P., Amman, C., Campbell, C., Ceschia, E., Clifton-Brown, J., Czobel, S., Domingues, R., Flechard, C., Fuhrer, J., Hensen, A., Horvath, L., Jones, M., Kasper, G., Martin, C., Nagy, Z., Neftel, A., Raschi, A., Baronti, S., Rees, R. M., Skiba, U., Stefani, P., Manca, G., Sutton, M., Tubaf, Z., and Valentini, R.: Full accounting of the greenhouse gas $\left(\mathrm{CO}_{2}, \mathrm{~N}_{2} \mathrm{O}, \mathrm{CH}_{4}\right)$ budget of nine European grassland sites, Agr. Ecosyst. Environ., 121, 121-134, 2007.
Stendahl, J., Lundin, L., and Nilsson, T.: The stone and boulder content of Swedish forest soils, Catena, 77, 285-291, 2009.

Stevens, A. and van Wesemael, B.: Soil organic carbon dynamics at the regional scale as influenced by land use history: a case study in forest soils from southern Belgium, Soil Use Manage., 24, 69-79, 2008.

Tamminen, P. and Derome, J.: Temporal trends in chemical parameters of upland forest soils in southern Finland, Silva. Fenn., 39, 313-330, 2005.

Tarnocai, C., Canadell, J. G., Schuur, E. A. G., Kuhry, P., Mazhitova, G., and Zimov, S.: Soil organic carbon pools in the northern circumpolar permafrost region, Global Biogeochem. Cy., 23, 11 pp., 2009.

van Meirvenne, M., Pannier, J., Hofman, G., and Louwagie, G.: Regional characterization of the long-term change in soil organic carbon under intensive agriculture, Soil Use Manage., 12, 86-94, 1996.

Vleeshouwers, L. M. and Verhagen, A.: Carbon emission and sequestration by agricultural land use: a model study for Europe, Glob. Change Biol., 8, 519-530, 2002.

von Lützow, M. and Kögel-Knabner, I.: Temperature sensitivity of soil organic matter decomposition-what do we know?, Biol. Fert. Soils, 46, 1-15, 2009.

Wuest, S. B.: Correction of Bulk Density and Sampling Method Biases Using Soil Mass per Unit Area, Soil Sci. Soc. Am. J., 73, 312-316, 2009.

Zhang, C. S. and McGrath, D.: Geostatistical and GIS analyses on soil organic carbon concentrations in grassland of southeastern Ireland from two different periods, Geoderma, 119, 261-275, 2004. 